\title{
Aproximaciones a la sexualidad popular: estudio comparativo de mujeres de tres contextos populares del Perú
}

\section{Carlos E. Aramburú Rosario Arias}

Este trabajo, desarrollado por un equipo multidisciplinario del Instituto Andino de Estudios en Población entre 1985 y 1987, explora las dimensiones culturales de la sexualidad y la fecundidad de mujeres de sectores populares del Perú.

Se trata de un intento de explicar los procesos culturales que inciden en las variables intermedias de la fecundidad, tales como la nupcialidad, la anticoncepción, la lactancia y en cierta medida el aborto. Estas dimensiones de la vida sexual y reproductiva se analizan con base en dos dimensiones explicativas: la generación y el contexto cultural de socialización. La hipótesis general es que se ha producido un proceso de homogenización cultural de los valores y conductas en torno a la sexualidad, de manera tal que las generaciones más jóvenes presentarán patrones conductuales y valorativos similares con independencia de su contexto de socialización, en tanto que entre los grupos de mayor edad, existirán diferencias contextuales en estas dimensiones.

Los métodos utilizados fueron: en una primera fase una encuesta demográfica en localidades seleccionadas previamente en función del nivel y ritmo de descenso de la fecundidad entre 1972-1981, y de su tradición cultural. Se seleccionaron así un distrito popular de Lima, la capital; un barrio pobre de una ciudad andina, Huaraz, y un pueblo rural costeño, Pueblo Nuevo. Algunos de los resultados que se presentan aquí se recogieron durante la segunda fase del estudio con base en la aplicación de métodos cualitativos tales como historias temáticas de vida y grupos focales. La muestra estuvo formada por 60 mujeres unidas pertenecientes a cuatro grupos de edad: 20 a 25; 25 a 29; 30 a 34 y 35 años y más. Mediante las historias de vida se buscaba recoger los testimonios individuales en torno a la sexualidad y la vida reproductiva, en tanto que los grupos focales tenían por objeto elucidar los valores grupales de cada grupo de edad en cada contexto, en torno a temas claves como las relaciones sexuales prematrimoniales, el enamoramiento, la imagen de género, el aborto, la anticoncepción, etcétera.

El análisis contrasta tanto la dimensión generacional como la contextual para cada uno de los temas o momentos de la vida sexual y reproductiva de estas mujeres, comparando las conductas individuales con los valores grupales. Resulta imposible resumir la riqueza y complejidad de los resultados, cabe sólo anotar que algunas dimensiones que cruzan los diferentes temas son: la contradicción entre las conductas individuales y los valores grupales (por ejemplo, con respecto a la virginidad y el aborto), el desamparo y la desinformación de estas mujeres con respecto a su vida sexual y afectiva; el poco control que ejercen sobre sus 
propias vidas; la persistencia de valores tradicionales con respecto a los roles de género, la maternidad y en menor medida la anticoncepción, y la persistencia de tradiciones socializadoras represivas y desinformantes en torno a la sexualidad.

Dos dimensiones teóricas que emergen del estudio como hipótesis para trabajos futuros se refieren, la primera al proceso cognoscitivo de la sexualidad, en donde en general la experiencia precede a la explicación del hecho, y la segunda en relación con el escaso o nulo control de sus vidas, lo que limita la capacidad de planear su futuro aun en los aspectos más intimamente vinculados con su rol de esposas y madres.

\section{Introducción}

Esta ponencia recoge algunos temas que forman parte de un trabajo más amplio sobre la sexualidad de sectores populares peruanos. Esta línea de trabajo fue iniciada en 1985 por un equipo interdisciplinario del Instituto Andino de Estudios en Población (INANDEP) con la intención de vincular la abundante investigación estadística referente a los cambios demográficos, en especial la concerniente al descenso de la fecundidad, con los cambios culturales en el rol de la mujer, la sexualidad popular y la estructura familiar, temas que han carecido de un intento de análisis conjunto.

Los resultados que aquí se presentan provienen de la segunda fase del estudio, la cual se realizó luego de analizar los resultados de una encuesta aplicada a una muestra representativa de la población de cada una de las localidades seleccionadas. Estas localidades fueron escogidas a partir de un análisis detallado del descenso de la fecundidad entre 1961 y 1981 . Resultaba evidente en los datos estadísticos disponibles tanto de fuentes secundarias como de la propia encuesta que el proceso de descenso de la fecundidad presentaba importantes diferencias en su ritmo y nivel entre las distintas unidades geográficas y según ciertas características de la mujer (nivel educativo, condición migratoria, etc.). Estas diferencias cualitativas eran fuertes indicios de procesos de cambio social y cultural subyacentes relativos sobre todo a cambios en la vida reproductiva y sexual de la mujer. Sin embargo nos encontramos con que el tema de la sexualidad popular era en gran medida una realidad sin teoría. Los pocos estudios contemporáneos existentes en el Perú sobre dimensiones de la sexualidad femenina, tenían una aproximación psicológica o clínica y estaban basados en casos de los sectores medios y altos quienes contaban con los recursos para acercarse al diván del psicólogo o psiquiatra. Nuestro intento en esta investigación exploratoria pre- 
tendía centrarse en la sexualidad de mujeres de sectores populares de diferentes contextos culturales, y además pretendía hacerlo desde una perspectiva socio-cultural, esto es, resaltando las normas y valores de cada grupo así como la sexualidad real, es decir la experiencia individual de cada mujer. Adicionalmente, intentamos aproximarnos a dos tipos de variables explicativas del cambio en la sexualidad; la generación y el contexto cultural. Como se explica más adelante, estas dos variables constituyen los ejes del estudio.

La fase de campo del estudio cualitativo se realizó en las tres localidades seleccionadas, entre julio y octubre de 1987, por un equipo conformado por la antropóloga María del Pilar Fortunic y la psicóloga Carmen Basurto del INANDEP quienes participaron también en el análisis preliminar de los datos con el apoyo del equipo de cómputo del INANDEP. El proyecto global fue financiado por la oficina para el Área Andina de la Fundación Ford. Nuestros sinceros agradecimientos a estas personas e instituciones por habernos estimulado a pensar y a comprometernos con este complejo y fascinante tema.

\section{Reflexiones e hipótesis}

La demografía ha intentado dar cuenta del proceso de descenso inicial de la mortalidad y de su secuela, el descenso de la fecundidad, a través del modelo de transición demográfica (Notestein, 1945). Innumerables revisiones y ajustes han precisado los aspectos fundamentalmente cuantitativos del modelo (Chakiel et al., 1991), y sus aplicaciones en distintos contextos geográficos y para distintos periodos (véase para el caso de Europa, Coale y Watkins, 1986, y para América Latina, Chakiel et al., 1991). Avances significativos se han logrado en estimar el ritmo y los diferenciales en el proceso de cambio de régimen de la mortalidad y sobre todo de la fecundidad (véase para el caso peruano, Aramburú y Ferrando, 1990). Notable es también el avance metodológico en explicar los determinantes próximos de la fecundidad (Boongarts et al., 1990). Sin embargo las dimensiones explicativas del proceso de transición demográfica, en especial en lo relativo al descenso de la fecundidad, se mantienen sustancialmente similares a las ofrecidas por el modelo original (un proceso de modernización, aumento de los niveles educativos de la mujer, cambio de norma familiar de extensa a nuclear, incremento de los costos vrs los beneficios económicos de los hiijos, etc.). Sin embargo estos procesos generales dejan de lado los problemas específicos que afron- 
tan diferentes generaciones en diferentes periodos y su manera de afrontarlos (MacLaren, 1990), en otras palabras, dejan de lado a los protagonistas sociales de carne y hueso cuyas conductas individuales, en tanto que agregadas en patrones colectivos, dan cuenta de los cambios en las grandes variables demográficas.

Desde una perspectiva antropológica, lo que se requiere es vincular el modelo de transición demográfica con uno de transición cultural del rol y status de la mujer respecto de su sexualidad y su vida reproductiva. Una base sólida para intentar este vínculo entre las dimensiones demográficas (básicamente cuantitativas) y las antropológicas (fundamentalmente cualitativas) es el modelo de determinantes próximos de la fecundidad de Boongarts (1990). En las aplicaciones de este modelo (basado en una versión simplificada del propuesto por Easterlin, 1978) y a través de un análisis comparativo entre países, Boongarts encuentra que cuatro de las variables intermedias tienen mayor fuerza explicativa al analizar la varianza entre los niveles de fecundidad de estos países. Estas variables son la nupcialidad (proporción de mujeres unidas por edad), la lactancia (duración media ), la contracepción (tasa de prevalencia y mezcla anticonceptiva) y el aborto (incidencia de aborto). Aunque este modelo tiene una expresión matemática, que mide el peso relativo de estas variables en el nivel de la fecundidad, todas estas variables intermedias cambian como resultado fundamental de procesos culturales. En otras palabras, el modelo de los determinantes próximos permite estimar el peso relativo de cada variable en el nivel y en el descenso de la fecundidad, si se cuentan con series históricas de estas variables. Sin embargo no explica, ni pretende explicar, los procesos que a su vez determinan los cambios en estos determinantes próximos. La literatura antropológica proporciona abundante evidencia de procesos de postergación de la edad al matrimonio en la medida en que las oportunidades educativas y laborales de las mujeres aumentan. Asimismo estos estudios ilustran el abandono de la práctica de lactancia exclusiva y prolongada en la medida en que la mujer tiene acceso a sucedáneos de la leche materna en el mercado y adopta normas modernizantes que restan valor a esta práctica, el incremento en el uso de anticonceptivos como resultado de un cambio de la sexualidad reproductiva hacia la sexualidad recreativa y las presiones económicas derivadas de una familia numerosa, y por último la incidencia del aborto, clandestino en casi toda América Latina, sea como método anticonceptivo o cuando éstos fallan. Cabe destacar que de estos cuatro procesos, es el del aborto y su contexto normativo e institucional, del cual se tiene menos evidencia estadística confiable para América Latina. 
Tanto el cambio relativo en cada una de estas dimensiones como los procesos y circunstancias a las que responden son culturalmente específicos y dependen tanto del contexto o ambiente cultural de socialización, como de la generación. En nuestra investigación hemos intentado aproximarnos a los procesos de cambio de estas variables tomando al contexto cultural y a la generación como variables explicativas. La hipótesis general plantea que la interacción entre contexto cultural y generación ocurre en la medida en que cohortes específicas de mujeres enfrentan contextos diferenciados que modifican sus roles y valores respecto de su vida reproductiva y su sexualidad. El proceso de homogeneización cultural afecta sobre todo a las generaciones más jóvenes por el impacto de la educación formal, el acceso a los medios masivos de comunicación, la migración, la incorporación, precaria la mayor parte de las veces, al mercado laboral y el cambio de dirección en los flujos de riqueza entre generaciones (Caldwell, 1988). Por tanto estas generaciones jóvenes están sujetas a un proceso socializador de la sexualidad más homogéneo entre los diferentes contextos culturales. En general el proceso de modernización supone una postergación de la edad de la unión, un cambio en la naturaleza del vínculo conyugal, un abandono de la lactancia exclusiva y prolongada, un mayor uso de la anticoncepción moderna, y el acceso al aborto en ocasiones extremas. Por el contrario, las cohortes mayores habrían experimentado un contexto socializador más diferenciado e influido en mayor medida por el entorno familiar más próximo (la familia de origen, el grupo de pertenencia y la familia de procreación). Por lo tanto encontraremos una mayor diversidad de patrones en la sexualidad y en la vida reproductiva de generaciones más viejas y un proceso tendiente a la homogenización entre las jóvenes.

A pesar de que estos procesos de cambio en la sexualidad y los patrones reproductivos tienen un resultado similar, la caída de la fecundidad marital, ocurren a ritmos diferentes y por procesos cuyas circunstancias varían en cada contexto cultural estando habitualmente signados por el conflicto (con las generaciones mayores y con los varones) y la contradicción (entre la norma ideal y la conducta real). Nuestro trabajo pretende ofrecer un modesto aporte para ilustrar la especificidad de estos procesos en tres contextos diferenciados y para distintas generaciones, revelando lo doloroso y contradictorio que representan estos cambios para las mujeres de sectores populares del Perú. 


\section{Metodología}

Como se ha señalado el estudio busca aproximarse a la sexualidad femenina de sectores populares analizando las diferencias por generación y según contextos culturales. La medición de la variable generacional se hizo dividiendo a la población informante por cohortes quinquenales de 20 a 24 años, 25 a 29 , 30 a 34 y 35 a más. Se trabajó un mínimo de cinco casos para cada una de las tres localidades y para cada una de las cuatro cohortes en el caso de las historias de vida. En los talleres grupales se trabajó con un mínimo de diez informantes para cada cohorte y en cada localidad.

La variable contextual se trabajó seleccionando a tres localidades de diferente tradición cultural y grado de modernidad, las que asimismo representaban casos diferenciados del proceso de descenso de la fecundidad. El análisis de diferentes censos y encuestas demográficas (censo de 1961, EDEN de 1974-1976 y ENDES de 1986) indicaban un descenso de $23 \%$ en la tasa global de fecundidad (TGF) nacional, de 6.85 a 5.26. Sin embargo este descenso había sido mucho más rápido entre los sectores populares de Lima $(38.5 \%)$, en contraste, entre las poblaciones rurales de la Costa y Sierra el descenso había sido leve y lento, un $3.6 \%$ y $6.5 \%$. El resto de las poblaciones urbanas de las 3 regiones naturales habían experimentado un descenso de la fecundidad que fluctuaba entre $22 \%$ (Sierra Urbana) y 36\% (ciudades mayores de 100 mil habitantes de la Costa) (véase el cuadro 1). En consecuencia y dada la imposibilidad de contar con suficientes casos como para ilustrar la diversidad del proceso, se seleccionaron tres localidades que representaban el caso de descenso más rápido, intermedio y lento de la fecundidad. Estas fueron un pueblo rural de la costa norte (Pueblo Nuevo), un barrio pobre de una ciudad andina (Huaraz) y un pueblo joven o villa miseria de Lima (El Agustino).

Las estimaciones del descenso de la fecundidad a nivel distrital para los años 1961-1972 y 1972-1981 y una encuesta previa en estas localidades permitieron estimar las dimensiones socio-demográficas de la población de estas localidades con base en una muestra de quinientas mujeres en edad reproductiva en cada lugar (INANDEP, 1988).

La muestra final del estudio en profundidad estuvo comprendida por 60 mujeres en edad fértil que estaban o habían estado en unión conyugal (casadas o convivientes) y que eran nacidas o tenían un mínimo de 5 años de residencia en la localidad. Estas mujeres fueron seleccionadas aleatoriamente de entre las encuestadas en la fase inicial del estudio y dependiendo de su voluntad para participar en la investigación. 
Se utilizaron dos técnicas básicas de recolección de información:

a) Las historias temáticas de vida. Se refirieron a entrevistas individuales en profundidad enfatizando las fases claves de la vida sexual y reproductiva y temas específicos de cada una de estas fases. El objetivo de las historias de vida era reconstruir la experiencia individual de cada mujer entrevistada para luego compararlas según cohortes y contexto cultural. Esta técnica se aplicó a una submuestra de cinco mujeres de cada cohorte elegidas entre las participantes de los talleres grupales de cada localidad.

b) Talleres de grupos focales. Consistían en cuatro sesiones de dos horas cada una para cada grupo de edad de cada localidad. En estos talleres se trabajaba con temas de motivación grupal (comprensión y valoración de conceptos claves en juego de tarjetas, historias sin final, oraciones incompletas, definición de roles, comentario de afiches, etcétera). Estas técnicas se utilizaron para tratar temas clave tales como el enamoramiento, las relaciones sexuales, los roles según género, la valoración y uso de anticonceptivos, la infidelidad, etcétera El objetivo de estos grupos focales era recoger los valores y apreciaciones colectivas en torno a distintos campos de la sexualidad y contrastarlos con las experiencias individuales recogidas en las historias de vida. El total de participantes en cada uno de los talleres fue variable, con un promedio de 120 mujeres en total (10 para cuatro grupos de edad en tres localidades).

El análisis consistió en el vaciado computarizado de la información individual en una matriz por temas y casos que permitía detectar en forma agregada los patrones comunes y las diferencias de la conducta sexual en cada contexto y generación. La información de los talleres permitió reconstruir los valores y las normas culturales del grupo referentes a la sexualidad ideal para así contrastarlas con la conducta sexual individual según generación y contexto.

En la medida de lo posible se ha tratado de intercalar en el texto las expresiones de las propias informantes para ilustrar mejor su forma de concebir su sexualidad y su vida reproductiva.

El análisis de los datos siguió el proceso cronológico de la vida sexual y reproductiva, incidiendo primero en los aspectos de la conducta real y luego en las diferencias por generación y contexto para culminar con el análisis de los valores y normas culturales ideales presentes en los grupos estudiados.

Las principales limitaciones del diseño y de la metodología utilizadas en el estudio son:

a) Cobertura limitada. El número de casos y el nivel de desa- 
gregación utilizada limitan la validez estadística de nuestras inferencias. Pese a la cuidadosa selección de los casos no pueden extrapolarse estimaciones cuantitativas válidas para la población total. Estas dimensiones fueron analizadas en la fase inicial del estudio basándose en una muestra representativa de la población femenina de cada localidad. Asimismo debe tenerse en cuenta que los tres contextos seleccionados no agotan la enorme variedad cultural y demográfica de la sociedad peruana.

b) Confiabilidad. Dada la complejidad del tema y su naturaleza sensitiva es necesario tomar con cautela las declaraciones de las informantes. El uso de dos técnicas independientes de recolección de información (historias de vida y grupos focales) otorga mayor confiabilidad a los resultados permitiendo contrastar las contradicciones de la norma ideal frente a la conducta real. En este sentido la ideologización de la sexualidad debe ser tomada como un dato de esta compleja realidad. El carácter multidisciplinario del equipo de trabajo hizo posible un análisis más equilibrado desde distintas perspectivas. La estadía prolongada del equipo de campo en cada localidad y el hecho de ser mujeres jóvenes contribuyeron también a ganar la confianza y amistad de las informantes.

c) Complejidad y cambio. El estudio de la sexualidad como fenómeno sociocultural reviste enorme complejidad. No sólo nos enfrentamos a una realidad sin teoría, sino que esta realidad está filtrada por la memoria y la racionalización del informante quien enfrenta estos temas influido por la normatividad y su propia afectividad. Un segundo factor de distorsión es el de la selección de temas y la interpretación del propio investigador. Debe además tenerse en cuenta que la sexualidad está en proceso continuo de cambio tanto generacional como normativo. Por ello una fotografía, aunque cuidadosa, no da cuenta de toda la película. Pese a estas limitaciones consideramos que tanto los métodos como los temas aquí abordados bien merecen el privilegio de la persistencia en su estudio y análisis.

Análisis y testimonios sobre la sexualidad popular

Sexualidad, enamoramiento y noviazgo

Los inicios de la sexualidad

Uno de los aspectos más sobresalientes vinculados con la sexualidad temprana es la falta de información. Quizás la primera experiencia relacionada con la sexualidad sea la menstruación. De las 
entrevistadas que hablaron del tema más de la mitad no sabían lo que les estaba sucediendo al momento de su primera menstruación, produciéndose como era de esperarse momentos de temor y ansiedad.

A los 12 años me pasó no sabía qué era, yo bien chiquilla, bien palomilla. Brinca pa'arriba, brinca pa'abajo, en una de esas brincadas sentí que mi calzón se me pegaba, me vi el calzón sucio, me asustó, jamás en la vida sabía que tenía que venir eso por ahí, me encerré en mi cuarto, mi mamá me dijo ven. ¡No!, pensé que iba a pegarme, a mi hermana le confesé, más confianza con ella me dijo que no me preocupe que era normal a todas las muchachas, de ahí todos los meses te va a venir, me quedé tranquila, después pensé ¿Todos los meses? ¿todos los días? ya me explicaron bien como era... (Leticia, 32 años; Pueblo Nuevo).

La falta de información trae consigo una serie de ideas erradas como que el sangrado se debe a que "...le habían tirado un patadón durmiendo" o a que estaba enferma:

...me asusté, trabajaba con mi patrona, llévame al doctor le dije... (Cecilia, 42 años; Pueblo Nuevo).

\section{Y no faltó quien se sintió próxima a la muerte:}

Yo veía que me bajaba sangre, me lavaba, no le decía a mi tía, después mi tío tocaba la puerta del baño que yo no salía del baño, le dije a mi tía, yo pues ignorante pensó 1 mes, 15 días, me iba a morir, después mi tía que era profesora con mi tío me explicó y me dijo que cada 26-28 días me iba a pasar así (Delia, 32 años; Huaraz).

La persona a la que recurrieron en estas circunstancias fue en primer lugar a la madre, luego a la hermana. Sin embargo en el contexto limeño, por la mayor desintegración familiar observada, muchas jóvenes se vieron obligadas a recurrir a parientes más lejanos o a personas ajenas a la familia.

En la mayoría de los casos la información que recibieron después de producido el hecho fue descriptiva y no explicativa del proceso biológico implicado. Es así que la explicación recibida no permitió relacionar la menstruación con la concepción y muchas de las que ya menstruaban desconocían su capacidad de convertirse en madres.

De mi primera menstruación me acuerdo que estaba en casa de mi madrina, tenía como 16 años, yo había escuchado del desarrollo que comienza, pero no sabía de qué se trataba, sentí que me mojé pero no 
tenía ganas de ir al baño, fui vi sangre, me asusté no comenté nada, no sabía si me iba a pasar algo más, estaba con esa angustia, no sé si es porque no tenía facilidad de conversar con otras personas desde niña que no comenté. Me pasó a los días y de ahí vi a la cocinera de mi madrina que lava su ropa, le pregunté qué le había pasado, me dijo que se había enfermado, me preguntó si yo ya, yo le dije que sí, ella me explicó que cada mes voy a menstruar, bien habladora era, me decía que ya podía tener hijos, ten cuidado que un hombre no abuse de ti, ya debes tener cuidado; ahora sí más bien las chicas hablan de todo eso, antes si más bien había ausentismo de todas esas cosas (Beni, 37 años; Lima).

El rol jugado por la institución escolar es bastante restringido ya que fueron muy pocas las entrevistadas que declararon haber recibido charlas informativas sobre el tema, las que así lo hicieron pertenecían en su totalidad a las generaciones más jóvenes. A pesar de que la muestra es muy pequeña la información obtenida apunta a una diferenciación regional, encontrándose Lima a la vanguardia en la incorporación de la educación sexual en las escuelas.

El papel de la familia y en especial de los padres es también bastante limitado en proporcionar información previa al hecho. Son pocas las que declararon que sus madres les dijeron que les iba a venir la menstruación. En estos casos la explicación que recibieron estuvo guiada por la preocupación materna por evitarle a su hija un susto cuando el hecho se produzca.

En su gran mayoría, los padres eluden su responsabilidad de dar información sexual a sus hijos por la incomodidad y los prejuicios en torno al tema de la sexualidad y por el temor de que la información proporcionada induzca a los jóvenes a una actividad sexual precoz para la que no se encuentran preparados. La vergüenza que sienten los adolescentes de tratar sobre estos temas con personas que no pertenecen a su grupo de edad y con respecto a las cuales no han desarrollado un sentimiento de solidaridad y confianza, refuerza la actitud de los padres de eludir su responsabilidad de dar alguna orientación sexual a sus hijos.

\section{Información sobre reproducción y sexualidad}

Como en el caso de los cambios biológicos de la joven, el rol de los padres en proporcionar información sobre sexualidad y reproducción es prácticamente nulo; 58 de las 60 entrevistadas no recibieron de sus madres ninguna información sobre el tema, llegando éstas en algunos casos a negarse a responder a las preguntas que sus hijas les formulaban: 
Con mi mamá no podía conversar decía que le faltaba al respeto, sólo con las de nuestra edad, nunca he preguntado nada.... Yo recuerdo que cuando le pregunté a mi tía dónde vienen los hijos me dijo que por el sobaco. Mi abuelita me dijo que por donde meas, pero antes de nacer tienes unos dolores fuertes, no me hablaban de estar con hombres... (Carmen, 24 años; Pueblo Nuevo).

En los pocos casos en los que las madres se atrevieron a tratar temas relacionados, su intervención no fue informativa y estuvo guiada por la inseguridad que sienten sobre lo que sus hijas puedan hacer a sus espaldas, llegándose también a proyectar su propio desengaño:

Cuando yo tenía 16, 17 recién mi mamá me conversaba de cómo con la pareja se vive, que vienen los hijos, me conversaba para estar sola, que no hay que estar junta con el hombre que no se vive feliz (Elva, 21 años; Lima).

Al igual que en el caso de la información sobre menstruación el rol que juega la escuela es bastante restringido. Sólo en el caso de Lima pocas jóvenes declararon haber recibido charlas al respecto. Tanto en la información más sistemática como en la informal se enfatizaron los riesgos de la relación sexual y el peligro que corre la joven de ser engañada por su pareja.

... Incluso las profesoras cuando había confianza nos hablaban del enamorado, que tengan cuidado, que si tienen algo con el enamorado tienen que cuidarse de esta manera con la regla nos decían, también decían que no se pasen del beso ni del abrazo (Elsa, 23 años; Huaraz). En cuarto año el profesor nos explicaba como era tener relaciones con el hombre. Nos decía que no tengamos miedo cuando se casen y el hombre les pida, que el pene del hombre es grande, va al útero de la mujer, mejor que sepan, nosotras nos reíamos cuando el profesor decía de la regla, del peligro de tener relaciones. Nos explicaba antes que tengan su regla están en peligro después ya no me acuerdo cuantos días se podía, también del jebe ese que se ponen los hombres, chicas cuídense que el hombre es más astuto, todas éramos de 13, de 12 años, el profesor era loretano, simpático (Maritza, 22 años; Huaraz).

Sin embargo es indiscutible que el sexo es un tema tabú también para los jóvenes, quienes en muchos casos se sienten incómodos de tratarlo. La palabra "vergüenza" aparece vinculada a la sexualidad en muchos de los testimonios analizados, llegándose a los extremos de no atreverse a preguntar o de preferir no ser informada por estar en presencia de compañeros del sexo opuesto. 
A los 16 o 17 años me dijeron: tú sólo besarte o abrazarte con tu enamorado, de la cintura para arriba. Yo decía ¿Por qué dirán eso? Cuando me pasó (se embarazó) ya me di cuenta porque, con razón dije (Frida, 35 años; Lima).

... En quinto un poco hablaban de sexo, de la fecundación, un profesor decía el hombre no debe burlarse de la mujer pero el colegio era mixto, las mujeres no queríamos que hable. Ya no es mixto, mucho problema había, recuerdo cuando estaba en cuarto la mayoría de las chicas de quinto salieron gestando, abortos, todo. Ahora en la mañana mujeres, en la tarde hombres... (Norma, 27 años, Lima).

Es indudable que la principal fuente de información con la que cuentan las jóvenes en relación con su sexualidad, son las amigas, es decir, las personas de su misma generación y de su mismo sexo con las que han desarrollado lazos de solidaridad y confianza. Sin embargo, no todas las jóvenes cuentan con alguna fuente de información, es así que encontramos un número elevado de ellas que llegan a experimentar una relación sexual sin haber desarrollado previamente ningún tipo de conocimiento teórico al respecto.

En relación con la variable generacional es indudable que las mujeres más informadas son las más jóvenes, y las de Lima con respecto al lugar de residencia. Siete de las 20 mujeres entrevistadas en Pueblo Nuevo no sabían nada acerca de las relaciones sexuales hasta que las experimentaron, e inclusive en ese momento algunas continuaron sin saber qué consecuencias podían desprenderse de sus actos:

Teníamos relaciones... yo ni sabía que podía quedar embarazada, él ni sabía tampoco, más muchacho que yo, tenía 15 años. Nunca me habían dicho cómo se tenían los hijos (Elena, 26 años; Pueblo Nuevo).

Es importante destacar lo inexacto que puede ser el término conocer, es por esta razón que sólo en estudios en profundidad como éste nos es posible acercarnos un poco más al mundo interior de la población estudiada y a los patrones y modelos que gobiernan su actuar.

Por su parte, nueve de las mujeres de Huaraz (de un total de 20) se enteraron de cómo eran las relaciones sexuales al unirse. En Lima la situación es bastante distinta ya que sólo una de las declarantes, migrante reciente, nos habla de una total ignorancia al respecto:

De relaciones no sabía nada cuando mi esposo trabajaba en chacra, estábamos despancando maíz, así a la fuerza me agarró, no era mi voluntad, él sí sabía, yo ahí recién supe de relaciones... (Nelly, 31 años; Lima). 
La ignorancia de las mujeres con respecto a este tema les impide establecer claramente cuáles son sus derechos en materia sexual, estando de esta forma expuestas a los designios del varón. Las personas que no tuvieron acceso a información alguna, guardan recuerdos angustiosos sobre el desarrollo de su sexualidad, sentimiento que se hace patente en muchos de los testimonios. La ignorancia de las mujeres sobre la reproducción humana las torna indefensas y les impide realmente decidir sobre su vida futura:

...nunca había conversado con nadie sobre relaciones sexuales, no sabía si se retiraba la regla o no. El me dijo que no me iba a pasar nada, yo no relacioné lo uno con lo otro (coito con embarazo)... (Juana, 32 años; Pueblo Nuevo).

Cuando relacionábamos yo le preguntaba qué era, él me dijo que seguía siendo virgen que no pasaba nada (Zoila, 32 años; Pueblo Nuevo).

A pesar de que muchas mujeres sintieron insatisfacción por la falta de información y de apoyo y sufrieron las consecuencias de su ignorancia, no están dispuestas a asumir un rol informativo y orientador con sus hijos. Pareciera que se sigue una norma implícita: "De esto no se habla hasta que ocurre".

El enamoramiento como realidad

El inicio de la relación de pareja, es decir el tipo de relación con los primeros enamorados o novios no sólo es, por lo común, la antesala de la nupcialidad, sino que signa el carácter de la relación de pareja. Las dimensiones cualitativas de la nupcialidad y del proceso que lleva a ella han sido obviados por la demografía formal (Samuel, Lerner y Quesnel, 1991). En las historias de vida de nuestras entrevistadas, el enamoramiento está muy relacionado con la primera relación sexual. El paso entre la atracción y la relación sexual parece ser muchas veces automático o en caso contrario las mujeres le restan importancia a un enamoramiento que no culmina en una relación sexual y es por esta razón que no lo mencionan en las historias de vida. Tanto en Pueblo Nuevo como en Huaraz sólo cuatro de las 20 mujeres entrevistadas en ambas zonas dijeron haber tenido otro enamorado antes de aquél con el que tuvieron la primera relación sexual. Sin embargo, en Lima nueve de las 20 informantes se refirieron a un enamorado anterior, lo que nos hace suponer que en un contexto más moderno y 
urbanizado el periodo de la adolescencia empieza a expandirse, a diferencia del mundo rural más tradicional en el que el paso de la niñez a la adultez se produce de forma abrupta.

En el contexto andino, sobre todo en las zonas rurales donde transcurrió la infancia de muchas de nuestras entrevistadas, encontramos patrones de comportamiento más tradicionales, donde el enamoramiento como etapa previa a la unión no existe y los padres son quienes deciden de manera autoritaria con respecto a la futura vida conyugal de su hija.

... pidieron mi mano a mi papá y me hicieron casar, ahí nos hacen casar sin conocer, ahí nosotros mismos no escogemos. Las chicas ahora ya no ordenan sus padres, nosotros allá en mi tierra, los padres hablan, los suegros escogen nuera, nosotros no hemos sabido escoger, yo tuve 15 años caminando, yo no pensaba siquiera. Así es la costumbre dicen... (Gloria, 40 años; Huaraz).

También se da el caso en que la decisión del pretendiente es aceptada por la mujer sin que exista un convencimiento de qué es lo que ella realmente desea hacer con su vida.

... entró a la fiesta y lo conocí a este borrachito, me preguntó donde estudiaba y yo le dije. Después me arrepentí ojalá que de borracho no se acuerde pero no, el lunes a primera hora estaba buscándome. Yo tenía otro enamorado, pero éste ya no me dejaba, me decía que si salía con otro me pegaba. Ya lo dejé al otro. Me buscaba todo el día, yo de miedo no más, me casé... de novios seguido me pegaba, un bruto era, hasta ahora, íbamos con él a reunión y conversaba con amigos y ya me pegaba, a veces lo veía en la calle y quería esconderme como si estuviera haciendo cosa mala, así me ha tenido como seis años. Como era muchacha no me había dado cuenta... de frente él sorprendió, vino a hablar con mi mamá, le llevó a su amigo más íntimo, le ayudó a hablar el muchacho, sólo no podía, yo escuchaba no más, ya estaba fregada. Vino con su pollo, con sus porquerías... me fui a casa de una amiga, ahí me fueron a buscar y ya quedaron para reunión (Lidia, 32 años; Huaraz).

En estos casos sea por presión familiar o la del pretendiente, coludido en ciertos casos con la familia, cuenta poco el deseo y la decisión de la joven. Sin embargo, el apoyo familiar genera una especie de responsabilidad que está motivada entre otras cosas por el temor a defraudar a sus padres cuando éstos han depositado su confianza en ellas. Es interesante señalar que todas las que resaltaron haber recibido apoyo de sus padres durante su enamoramiento llegaron a la unión por el matrimonio y que ninguna llegó a éste embarazada; entre ellas también se encontró a la única de las 60 
mujeres, que sé casó virgen. (Pertenecía a la zona de Pueblo Nuevo).

En el caso de Lima encontramos que, si bien es cierto que los padres son más permisivos en relación con los enamorados de sus hijas, la reacción con respecto a los embarazos prematuros es similar, generándose una oposición de la familia de ella, frente a la que se producen fugas en la mayoría de los casos con el apoyo de la familia del muchacho.

Persiste en estos contextos tradicionales la doble norma, el matrimonio es visto como bueno por la familia del varón y como riesgoso por la familia de la joven.

A los 25 años tuve mi tropiezo, tuve mi hijito, el hombre era de mi tierra, conocido. Yo me confié, después no reconoció a la criatura, seis años tiene, hombrecito es, vive con mis papás (Benita, 32 años; Lima).

En relación con el consentimiento de la familia de él, con respecto al enamoramiento, es poca la información consignada en las entrevistas. Sin embargo parece que el patrón normal de comportamiento es la oposición de la familia de la chica y una mayor tolerancia y muchas veces apoyo declarado de la familia de él. Esta actitud se explicaría por la creencia manifestada en los talleres de que el hombre es inestable, "palomilla" y que es justamente "buena" una relación temprana con una mujer, lo que corregiría la situación haciendo que el muchacho madure.

La familia de él sí estaba de acuerdo, la mía como todo padre no... (Julia, 20 años; Pueblo Nuevo).

Nosotros nos llevábamos bien, pero mi familia no se llevaba bien con él, le hacían problemas, la familia de él no hacía problemas (Teresa, 20 años; Pueblo Nuevo).

Como veremos a continuación serán las familias de los varones las que apoyarán en un primer momento las uniones jóvenes.

Estos patrones ideales con respecto al varón persisten a pesar de que en muchos casos las experiencias de las mujeres con su pareja les demuestra lo contrario, es decir que la conducta irresponsable del hombre continúa a pesar de estar casado, teniendo muchas veces que asumir ellas las responsabilidades de la vida de pareja. Esta es otra de las dimensiones de la sexualidad en que la norma ideal dista mucho de la realidad. 
Relaciones sexuales antes de la unión

Si bien en el nivel nacional las tasas de fecundidad entre adolescentes han descendido en los últimos 20 años, los diferenciales siguen siendo muy significativos. Entre las jóvenes rurales en tre 15 y 19 años, $25 \%$ estaba embarazada o ya era madre; entre las urbanas sólo $8 \%$. Mayor aún es el diferencial según nivel educativo; casi $37 \%$ de las jóvenes analfabetas de 15 a 19 años estaba embarazada o tenía por lo menos un hijo frente a sólo $2.7 \%$ de las que tenían educación superior en este grupo de edad (ENDES, 19911992: 37, cuadro 3.10). Estas diferencias en el embarazo adolescente no se explican por la nupcialidad más temprana entre las jóvenes rurales y analfabetas, pues la edad mediana a la unión es poco más de tres años más temprana en el medio rural y 2.5 años más temprana entre las analfabetas que entre las que tienen educación superior. Existen diferencias culturales que indican la mayor precocidad sexual entre las jóvenes rurales y analfabetas por la persistencia del "matrimonio de prueba" o "servinacuy" en el medio rural tradicional y por la mayor dominación del varón y nulo acceso a la anticoncepción en el caso de las jóvenes con bajos niveles educativos.

En nuestro estudio, encontramos que la mayoría de las mujeres entrevistadas mantuvieron relaciones sexuales antes de la unión, lo que dependía más de su situación familiar y nivel educativo que del contexto cultural de socialización.

En Pueblo Nuevo, por ejemplo, sólo una de las 20 mujeres entrevistadas no mantuvo relaciones sexuales antes de la unión, llegando virgen al matrimonio; cuatro se fugaron y después mantuvieron relaciones. En este tipo de fugas el papel del hombre en la decisión de fugarse es fundamental, llegando algunas mujeres a declarar que ellos las obligaron o robaron.

Huaraz se presenta como un contexto menos permisivo que el anterior por la mayor cohesión familiar e influencia de los padres. Nueve de las veinte entrevistadas mantuvieron relaciones sexuales antes de la unión, de éstas, cuatro pertenecían al grupo de las más jóvenes, lo que nos conduce a afirmar la existencia de un cambio hacia una mayor permisividad sexual entre las más jóvenes.

En Lima 14 de la 20 entrevistadas tuvieron relaciones coitales antes de formalizar su unión. Teniendo en cuenta que muchas de estas jóvenes provienen del medio andino, puede caracterizarse a Lima como un contexto en que la desestructuración familiar, el desamparo de la joven migrante y los cambios culturales favorecen su iniciación sexual precoz. 
Resulta sorprendente que la totalidad de las jóvenes de Lima y Huaraz y la mayoría de las de Pueblo Nuevo que mantuvieron relaciones sexuales antes de la unión resultaron embarazadas.

Esto es consecuencia de la casi total ausencia de uso de métodos anticonceptivos, cuestión que como veremos más adelante no solamente está motivada por la ignorancia o el temor sino por una valoración cultural que las hace juzgar en forma negativa a la joven que usó de estos métodos durante el enamoramiento.

Con el que es mi esposo ahora, antes de juntarnos tuvimos (relaciones), me entregue en Huancayo, una sola vez tuvimos y ya no me enfermé. Le conté a mi amiga y me dijo tu eres cojuda, monga, una vez y ya, piña, me preparó ruda, todo y nada (Chabela, 25 años; Lima).

Otro aspecto sumamente relevante del inicio de las relaciones sexuales son las circunstancias en que éstas se dieron. En el contexto rural sólo 2 de las 19 que mantuvieron relaciones antes de la unión, fueron forzadas por el enamorado:

Ahí en la playa tuve miedo y vergüenza, primera vez que uno se ve con un hombre. El se portó con exigimiento, tenía vergüenza bastante, me sentía mal mucho sangraba, no me sentí bien ningún rato (Vitalia, 34 años; P.N.).

Por el contrario, en el caso de Lima seis de las 14 que experimentaron una relación coital antes de la unión, declararon haber sido forzadas u obligadas a tenerlas por la pareja.

Relaciones tuve a los 16 años, como era estudiante mi enamorado me dijo que su mamá quería verme. Fuimos y me encerró en la casa, tuvimos relaciones, me forzó, yo no sabía... (Norma, 27 años; Lima).

De mis primeras relaciones no me podía ni sentar, me dolía, orinar me dolía, 15 años tenía. El como estaba mareado me decía ¿qué le voy a hacer?, aceptarle no más (Amalia, 22 años; Lima).

La primera vez me asusté, estaba enferma como 15 días, mis hermanos querían llevarme al hospital, yo no quería, tenía miedo. Hubo un esfuerzo máximo, incluso le arañé la cara al hombre, pero nada, fue un poco violento. Ha sido en contra de mi voluntad, no fue una entrega total, yo no quería saber nada, me desaparecí (Frida, 35 años; Lima).

En Huaraz, por el contrario, sólo una de las mujeres admite haber sido violentada en su primera relación sexual.

Aparentemente en Lima por tratarse de un contexto social más despersonalizado y amplio, las relaciones interpersonales están sujetas a un menor control social de los padres y parientes. A ello contribuye la ausencia de tutela de los padres por la 
alta proporción de familias de reemplazo. La violencia del joven en la primera relación sexual está sujeta así a menor sanción.

Es indiscutible que esta primera experiencia traumática, condiciona la desvalorización del placer sexual para la mujer, actitud que prevalece en muchos de los testimonios recogidos. Asimismo, el embarazo es la consecuencia inevitable de esta actividad sexual por la ausencia de contracepción efectiva, lo que puede resultar en una unión no planeada o en el peor de los casos en el abandono de la joven embarazada.

\section{Valoraciones de las relaciones sexuales antes de la unión}

Como vimos anteriormente las relaciones sexuales antes de la unión son el patrón de comportamiento más frecuente en contextos más modernizados como Pueblo Nuevo y Lima y se dan cada vez con mayor frecuencia en contextos tradicionales como Huaraz. A pesar de ello, son muy pocas las entrevistadas que las consideran "buenas".

Sin embargo, el rechazo a la sexualidad pre-nupcial no alude a una convicción moral, sino al temor a las consecuencias de dicha conducta y al rechazo social;

No es dable, trae consecuencias de ahí vienen los pesares... los hombres... ya no tienen la posibilidad de casarse con ellas, se les llama fáciles (Maritza, 26 años; Pueblo Nuevo).

Otras expresaron su rechazo directamente al hablar de lo que desearían para sus hijos. Aquí también encontramos, como analizaremos más adelante, el anhelo del matrimonio de blanco, presente en la imaginería de tantas mujeres. Es decir, a pesar de existir una mayor libertad sexual, la mayoría de las mujeres conciben a la relación sexual previa a la unión como un preámbulo y más aún un motor para que ésta se realice, subsistiendo veladamente en la mente de las mujeres la valoración de la virginidad como requisito para asegurar el matrimonio.

Un aspecto sumamente revelador de las relaciones sexuales antes de la unión es la transferencia de la responsabilidad hacia el novio o enamorado. Son frecuentes las referencias a que el hombre exigió "la prueba del amor, las palabreó o las convenció". Esto es sobre todo frecuente entre las más jóvenes de Lima y Pueblo Nuevo.

A los 15 años conocí a mi enamorado, salíamos a pasear, a conversar, él me pedía para estar y yo no le tomaba importancia. Le decía que él era más mayor siete años más, pero los hombres son más..., 
me palabreaba me convenció, me decía que se iba a casar conmigo (Amalia, 22 años; Lima).

La preocupación más frecuente de las mujeres con respecto al tema es que una relación prematura puede desembocar en un embarazo no deseado. En segundo lugar está el temor a la promiscuidad, es decir, a ser abandonada por su pareja no pudiendo lograr luego el respeto y amor de otro hombre. De esta manera el "qué dirán" y la idea de ser calificada de mujer fácil también están presentes entre las preocupaciones de las mujeres.

Sin embargo, nos atreveríamos a decir que el temor ante un embarazo no deseado está condicionado por la situación de abandono. En otras palabras, si hay unión ya no existe ninguna justificación para retardar el embarazo, a diferencia de lo que ocurre en otras clases sociales. El que la mujer sea muy joven o no haya concluido su educación no son razones suficientes para retardar la llegada de los hijos.

Hay una fuerte ligazón con el presente que hace relativa la validez de los proyectos de vida hacia el futuro. En este sentido los sucesos se van dando y van envolviendo a los personajes, sin que la decisión personal pueda oponerse a lo que de todos modos iba a ocurrir, es "el destino".

La mujer debe cumplir su rol de madre y probar con ello no sólo la virilidad de su pareja, sino su propia honestidad. La mujer decente que tiene relaciones debe salir embarazada y si esto no ocurre puede perder a su pareja.

Tenía relaciones sexuales con él, no me cuidaba con nada, yo recuerdo qué hice después de mi regla, él se ponía un jebecito, como dos o tres años fuimos juntos, pero una chica se quedó embarazada de él. Hicimos planes para casarnos y todo, él decía que no es la primera vez así que varios hogares con otros hijos. Yo ya no quería, después me conocí con mi esposo, si me quería tenía que comprender. Relaciones con él (actual esposo) hice en el mes de noviembre y el día 20, mi santo, ya estaba embarazada (Sorlisa, 20 años; Huaraz).

Esto prueba la necesidad de salir embarazada, que se constituye en un seguro para retener a la pareja. Este estereotipo, presente en la mente de las mujeres, aparece también en los mensajes telenovelescos en los que la mujer buena, a través de su maternidad, logra vencer todos los obstáculos y retener al galán de sus sueños.

En suma, la sexualidad prenupcial carece de valor por sí misma, como medio para conocerse y como experiencia placentera; es fundamentalmente un mecanismo para "asegurar" al varón y por lo tanto el futuro. Por ello lo reprobable no es la actividad se- 
xual y el embarazo antes de la unión, sino el abandono y el fracaso en retener a la pareja pese a esta "entrega".

CUADRO 1

Relaciones sexuales antes de la unión

\begin{tabular}{|c|c|c|c|c|c|}
\hline & \multicolumn{2}{|c|}{$\begin{array}{l}\text { Mantuvo } \\
\text { relaciones sexuales } \\
\text { antes de la unión }\end{array}$} & $\begin{array}{l}\text { Relaciones } \\
\text { forzadas }\end{array}$ & $\begin{array}{c}\text { Usó anti- } \\
\text { conceptivos }\end{array}$ & Cuáles \\
\hline $\begin{array}{l}\text { Pueblo } \\
\text { Nuevo }\end{array}$ & $\begin{array}{l}\text { Sí } \\
19\end{array}$ & $\begin{array}{c}\text { No } \\
1\end{array}$ & 2 & 5 & $\begin{array}{l}\text { Ritmo } \\
\text { condón } \\
\text { retiro }\end{array}$ \\
\hline Huaraz & 9 & 11 & 1 & 2 & $\begin{array}{l}\text { Ritmo } \\
\text { condón }\end{array}$ \\
\hline Lima & 14 & 6 & 6 & - & - \\
\hline
\end{tabular}

\section{La nupcialidad}

En el estudio del descenso de la fecundidad se ha atribuido poca importancia a la nupcialidad por considerar que ésta ha cambiado poco en sus dimensiones cuantitativas (Samuel, Lerner y Quesnel, 1993). La evidencia reciente para Perú parece confirmar esta tesis; en los últimos 20 años (1970-1990) la edad mediana al matrimonio sólo aumentó de 21 a 22 años (ENDES, 1991-1992: 59). Asimismo, el estado conyugal entre las mujeres de 15 a 49 años presenta poca variación con $38 \%$ de casadas, $37 \%$ de solteras, casi $18 \%$ de convivientes, y un $5 \%$ de divorciadas o separadas. Sin embargo los diferenciales generacionales son notables; entre las mujeres mayores ( 45 a 49 años) $45 \%$ se casaron antes de los 18 años, en tanto que entre las jóvenes de 20 a 24 sólo $31 \%$ se casaron antes de los 18 (ENDES, 1991-1992: 64); asimismo, entre las mujeres rurales, el inicio de la unión es casi 5 años más temprana que entre las urbanas. Curiosamente los diferenciales en la edad a la unión son menos notables según el nivel educativo de la mujer; las analfabetas se casan solamente 2.5 años antes que las que han completado su educación secundaria.

En este trabajo nos interesa abordar los aspectos cualitativos de la nupcialidad, referentes al contraste entre la visión ideal y la realidad de la vida en pareja, el proceso que lleva al matrimonio y el carácter de la relación de pareja, en especial en lo concerniente 
a la sexualidad marital. Estas dimensiones cualitativas de la nupcialidad son relevantes para entender más precisamente el proceso de toma de decisiones con respecto al embarazo, la anticoncepción y, en general, de la vida reproductiva. Todo esto puede contribuir a entender mejor los procesos que en los niveles individual, familiar y social, condicionan los cambios en la fecundidad.

\section{Matrimonio ideal}

En los grupos focales se planteó una visión romántica del matrimonio siendo el amor prácticamente el único requisito. Sin embargo, encontramos algunos matices diferentes en la visión ideal del matrimonio según generación y contexto. Entre las mayores y en los contextos más modernizados se enfatizó la importancia de la viabilidad económica de la joven pareja. No obstante, la responsabilidad es atribuida exclusivamente al varón, en tanto que el rol ideal de la mujer alude a sus funciones de ama de casa, esposa y madre. Planear las cosas calmadamente para lograr las mejores condiciones frente a las decisiones de iniciar una vida en pareja, no está dentro del comportamiento real de la mayoría de las mujeres.

Otro elemento fundamental de la imagen ideal del matrimonio es el de la ritualidad. El casarse de "blanco" es el mayor anhelo de las mujeres. En las tres zonas estudiadas encontramos el mismo sueño; el matrimonio ideal supone además una fiesta con comida, trago y baile; un momento de reunión con amigos y familiares. Estas declaraciones contrastan con su verdadera situación pues conversando con muchas de las participantes en los talleres, vimos que son muy pocas las casadas por la Iglesia y menos aún "de blanco". Más bien sus declaraciones sobre la ceremonia son una proyección de una situación que ellas viven indirectamente, todos los días, a través de las historias de amor que la televisión difunde.

En las historias de vida encontramos también que lo primero que asocian las mujeres cuando se habla de matrimonio es el momento de la ceremonia y no la institución familiar y todo lo que ésta supone. El ideal del matrimonio de blanco está presente en la mente de la mayoría de las mujeres. Pensamos que "casarse de blanco", no es para todas símbolo de virginidad y pureza, ya que algunas de las que estaban de acuerdo con las relaciones sexuales prematrimoniales o que eran un tanto ambiguas al respecto, sostuvieron que el matrimonio ideal debe efectuarse de blanco. El blanco se ha convertido más bien en un símbolo de aceptación familiar y reconocimiento social y alude principalmente a la fiesta 
que debe acompañar a la ceremonia del matrimonio, como una demostración del bienestar económico de la familia y de la formalización ritual de la unión.

Sólo una minoría de los tres contextos estudiados iniciaron su vida conyugal a través del matrimonio formal y menos aún fueron las que gozaron de la anhelada celebración matrimonial.

La formalización del matrimonio después de un tiempo de convivencia es en realidad el patrón predominante. En el contexto andino principalmente, el compromiso, es decir la formalización de la relación, es sumamente importante y se efectúa con la visita de los familiares del novio a los padres de la novia, para pedirla. Dicho acto está cargado de connotaciones de aprecio y respeto familiar y social:

... Así pasó meses, meses y nos comprometimos o que él vino solito, mi papá dijo que venga con su papá, su mamá, mi hija no es perro para soltarla así no más... (Igima, 25 años; Huaraz).

La importancia de la "pedida de mano" se exterioriza con la fiesta, símbolo de la autoridad familiar, y rito que marca la finalización de una etapa de la vida y el inicio de otra:

... Después de lo que hablaron con mi mamá pasaron unos meses y nos juntamos, me fui así no más, no hubo fiesta, creo que acá se festeja cuando se casa, nosotros no, cuando pidió mi mano sí hicieron fiesta... (Rosalía, 27 años, Huaraz)

Al hablar del matrimonio, fueron muy pocas las mujeres que lograron proyectarse hacia el futuro desligándose de las circunstancias del casamiento; en la mayoría de los casos no fueron más allá de lo que sería el "final feliz" de cualquier telenovela, es decir la unión de la pareja en el matrimonio como triunfo frente a la adversidad y momento culminante que le resta importancia a la vida que continúa después de la ceremonia.

Es indudable la importancia del rito y la ceremonia para las clases populares, ya que en la mayoría de los casos, el matrimonio supone la formalización de una situación de "facto" y, por lo tanto, el reconocimiento y aceptación social. Es el reingreso al orden, después del caos inicial. En Pueblo Nuevo 14 de las 20 entrevistadas llegaron a casarse, mientras que en Huaraz y Lima sólo 7 llegaron a hacerlo. El matrimonio real que se llevó a cabo en la mayoría de los casos estuvo muy lejos de sus expectativas. 


\section{Matrimonio como realidad}

El proceso de inicio de la unión presenta diferencias contextuales importantes que parecen repetirse a través de las generaciones. En el medio rural de Pueblo Nuevo, la fuga y la formalización posterior parece ser el patrón predominante.

... me ofreció para irme con él que trabajaba en Trujillo...hasta que un día me fui. Yo les había dicho a mis papás, mi mamá no quería, papá callado. El (novio) iba a venir a pedir mi mano aunque fuese casado, mi mamá no quiso y no se atrevió. Yo no le dije a nadie, de un momento a otro me fui, él ya había hablado con sus padres... cuando recién me fui tuvimos relaciones; él no me había propuesto nada, muy caballero, nada de pecador (Elsa, 28 años; Pueblo Nuevo).

El mecanismo de la fuga como forma de iniciación de la vida en pareja parece ser independiente de las razones que la motivan, que van desde el embarazo, el deseo de asegurar al novio después de haber mantenido relaciones con él, o la necesidad de hacer que los padres acepten una situación ya consumada.

El patrón más común con el que se inicia la unión en el contexto andino (Huaraz) es el arreglo familiar o el compromiso; como manifestamos anteriormente, la formalización tiene gran fuerza en este contexto.

Es interesante señalar, que a pesar de la importancia que las mujeres atribuyen al matrimonio, es minoría la que inicia su vida en pareja a través del cumplimiento de este rito. Especialmente en Lima sólo una de cada cuatro entrevistadas iniciaron su vida conyugal a través del matrimonio. Para la mayoría, debido a la desintegración familiar no hubo ritualización que marcara el inicio de la vida en pareja.

\section{Valoración del cambio de roles}

Todas las mujeres de los distintos grupos de edad manifestaron sentirse libres antes del matrimonio, para divertirse y salir, para estudiar e inclusive para viajar. En general todas mostraron una actitud positiva con respecto a la familia de origen. Pensamos que esto supone una idealización ya que en las historias de vida muchas destacaron la falta de libertad y los continuos controles a los que fueron sometidas por sus padres.

Sus opiniones con respecto a las actividades de las mujeres después del matrimonio reflejan las limitaciones que la vida con- 
yugal y la presencia de los hijos les imponen. La sumisión al marido les impide decidir sobre su vida. Los celos y el machismo se encuentran claramente reflejados en afirmaciones como:

— "No puedo salir ni a botar la basura porque mi esposo es celoso" (Huaraz)

— "Hay que atender al esposo y al bebé" (P.N.)

- "Ya no puedo salir" (P.N.)

— "Salgo, pero discutiendo un poco con mi esposo" (P.N.)

— "No tengo libertad para mí misma" (P.N.)

Una de las limitaciones mayores que expresaron las mujeres participantes en los talleres de Lima, fue la imposibilidad de trabajar y de estudiar como consecuencia de su situación de casadas.

Los grupos mayores expresaron un sentimiento mayor de libertad que el resto, debido a la mayor estabilidad en su relación de pareja y también a una cierta liberación con respecto a los hijos, muchos de los cuales pueden evidentemente valerse por sí mismos por ser mayores.

\section{Motivos para casarse}

En este taller se les entregó una hoja a las asistentes con dos frases incompletas: "Me casé porque..."; "No me hubiera casado si es que...".

Las razones que dieron las mujeres para haberse casado son principalmente el amor expresado de distintas maneras: "Estaba enamorada", "lo quería”, "era bueno y me gustaba", "nos comprendíamos". Hay otras que más bien lo presentan como una forma de mejorar su situación actual, ya sea porque han tenido relaciones sexuales y temen al qué dirán, porque necesitan apoyo y protección de alguien, porque no les gustaba su vida en la familia de origen, o simplemente porque no querían ser solteras por más tiempo. Finalmente están las más negativas que manifestaron haberse casado porque no tenían experiencia, no sabían lo que eso suponía.

A pesar de que en las tres zonas estudiadas se dan básicamente las mismas razones para casarse, encontramos que en Huaraz las mujeres pusieron mayor énfasis en el embarazo como motivo de la unión. En Lima, además de esta última razón, aparece el ansia de escaparse del tutelaje de los padres sustitutos (tíos, padrinos, empleadores) problemática que se agudiza por el proceso de desintegración familiar que resulta de la migración femenina. 


\section{Roles conyugales}

Las opiniones vertidas en este tema son producto de una reunión de grupo donde se conversó sobre la mujer, el hombre y las responsabilidades de cada uno. Esta reunión como todas las anteriores se realizó de manera independiente para cada uno de los grupos de edad.

Fue una opinión generalizada el atribuir más ventajas al hecho de ser varón, mientras que encontraron pocos y dudosos beneficios a su condición de mujeres. El contraste es notable para los casos de Lima y Huaraz, basta observar en el cuadro 2 la larga lista de ventajas atribuidas al hecho de ser varón y la igualmente larga lista de las desventajas de ser mujer. Ello revela una baja autoestima de la mujer, incluso en las localidades más modernizadas (como Lima) y refleja además un hecho objetivo, las duras condiciones de vida de la mujer en los sectores populares y la persistencia del machismo en estos contextos.

\section{Ventajas y desventajas de ser hombre o mujer}

Antes de desarrollar el tema es necesario aclarar que si bien la finalidad de estos talleres apuntaba hacia situaciones ideales, sin embargo las opiniones vertidas están muy apegadas a la realidad vivida por las mujeres participantes (véase el cuadro 2).

La primera ventaja de ser hombre está relacionada con la libertad. El hombre puede hacer lo que quiera sin pedir permiso a nadie. En esta opinión generalizada, las mujeres se están refiriendo a las posibilidades de divertirse, de salir con amigos, de no tener la responsabilidad de la casa y los hijos. En este contexto, inclusive el poder emborracharse es visto paradójicamente como una ventaja. Esto está relacionado con la doble moral que permite ciertas cosas a los hombres pero las niega para las mujeres. Esta valoración tiene implicancias en la forma de entender la libertad sexual, el hombre puede tener relaciones con muchas mujeres y además puede exigirle a su esposa tener relaciones sexuales cuando así lo desee. El control ejercido por el varón está vinculado con las ventajas físicas propias de la masculinidad: los hombres no se embarazan ni menstruan y son físicamente más fuertes que las mujeres. La relación del hombre con los hijos es vista de forma contradictoria por la mujeres. Es así que, por ejemplo, las participantes más jóvenes en los talleres de Huaraz vieron por un lado como una ventaja del hombre el no poder tener hijos; mientras que el grupo mayor ( 30 a 34 años) manifestó como una de sus ma- 
yores ventajas el que pueden tener todos los hijos que quieran; esta opinión estaría vinculada con la posibilidad del varón de formar varias familias paralelas y estuvo presente también en los otros contextos analizados. Por último, el grupo de las mayores consideró que una de las ventajas del hombre era que no tenía que atender a los hijos cuando estos se enfermaban. Todas estas declaraciones traslucen el comportamiento de sus parejas en el hogar y cómo ellas viven su relación con sus esposos. La libertad de la que ellos gozan y la dominación que ejercen sobre ellas, juntamente con la falta de responsabilidad está representada en muchas de las opiniones vertidas, llegándose a decir por ejemplo que una de las ventajas de ser varón es que "no tiene dignidad (es sinvergüenza)”.

Otra de las ventajas de ser hombre es que no tiene que realizar quehaceres domésticos y que puede trabajar en lo que quiera. Sin embargo en oposición a esto, tanto los tres grupos más jóvenes en Pueblo Nuevo como los tres mayores en Huaraz y dos grupos de Lima dijeron que la mayor desventaja de ser hombre era el tener que trabajar para mantener a la familia. Es significativo ver que la mayoría de los grupos sólo pudo encontrar una desventaja al hecho de ser varón, mientras que encontraron entre 8 y 10 desventajas a ser mujer. Las más jóvenes de Huaraz expresaron que el no poder usar “... aretes ni alhajas" era la única desventaja de ser hombre y el poderlo hacer, una de las pocas ventajas de ser mujeres; mientras que las mayores de Pueblo Nuevo precisaron otro tipo de desventajas tales como no poder llorar y no saber expresar su cariño a sus hijos (véase el cuadro 2).

Como podemos apreciar en los párrafos anteriores, las mujeres presentan una imagen estereotipada de aquello que dentro de su cultura supone la masculinidad. Sin embargo, muchas de las ventajas atribuidas al hecho de ser hombre, tales como ser borrachos o egoístas, son inexplicables y rechazadas por las mujeres a nivel individual.

$\mathrm{Al}$ poner las características atribuidas a hombres y mujeres en un cuadro de oposiciones vemos que muchas se compensan. La libertad social del hombre conlleva una obligación en el trabajo. La falta de libertad de la mujer supone un mejor trato social y una cierta protección económica. El hombre se impone por la fuerza, pero la mujer coquetea y llora. El hombre no cuida su apariencia y exige, pero la mujer se adorna y lo seduce. Sin embargo, es claro que en la visión de estas mujeres el hombre resulta siempre el ganador, es más.

Tal vez una de las características más importantes en la visión que las mujeres tienen sobre los roles sexuales, se refiere a 
que mientras que el hombre es visto como egoísta, la mujer es considerada sacrificada. Es decir, a un nivel teórico, al hombre se le perdonan muchos defectos, ya que se suponen naturales a su condición de varón. Dichas características las encontramos presentes, por ejemplo, en innumerables mensajes telenovelescos de gran aceptación en América Latina. Sin embargo, como veremos en las historias de vida, el hombre real no es ni tan poderoso ni tan libre, como la mujer lo imagina, pero de hecho ejerce dominación sobre ella.

Características que oponen a hombres y a mujeres

Libre

Hombre

Muchas mujeres

Se emborracha

No hace quehaceres domésticos

Iniciativa sexual

No se embaraza

No menstrua

Más fuerte

No cuida su físico

No es sensible /no llora

Puede usar la ropa que quiera

No usa joyas, cosméticos

No le dan preferencia

Tiene que trabajar

Egoísta

Libertad de trabajar en cualquier

cosa

No es coqueto

No usa anticonceptivos

Decide en educación de sus hijos
Mujer

Subordinada

Un hombre

No

Sí hace quehaceres

No

Se embaraza

Menstrua

Delicada / temerosa

Pretenciosa

Sensible /llora

Usa la ropa según gusto del marido

Usa joyas, cosméticos

Sí le dan preferencia

No tiene que trabajar

Dada/ útil para sus hijos

No tiene libertad...

Coqueta

Usa anticonceptivos

No decide en educación.

Roles: masculino y femenino

Los resultados obtenidos no difieren de la visión tradicional que se tiene sobre el rol de cada sexo. Al hablar sobre el papel de la mujer en la sociedad todos los grupos de edad de todas las localidades coincidieron en que el rol principal de la mujer es tener hijos, encargarse de la alimentación y las otras necesidades de las que depende el bienestar hogareño. El rol de madre es el predomi- 


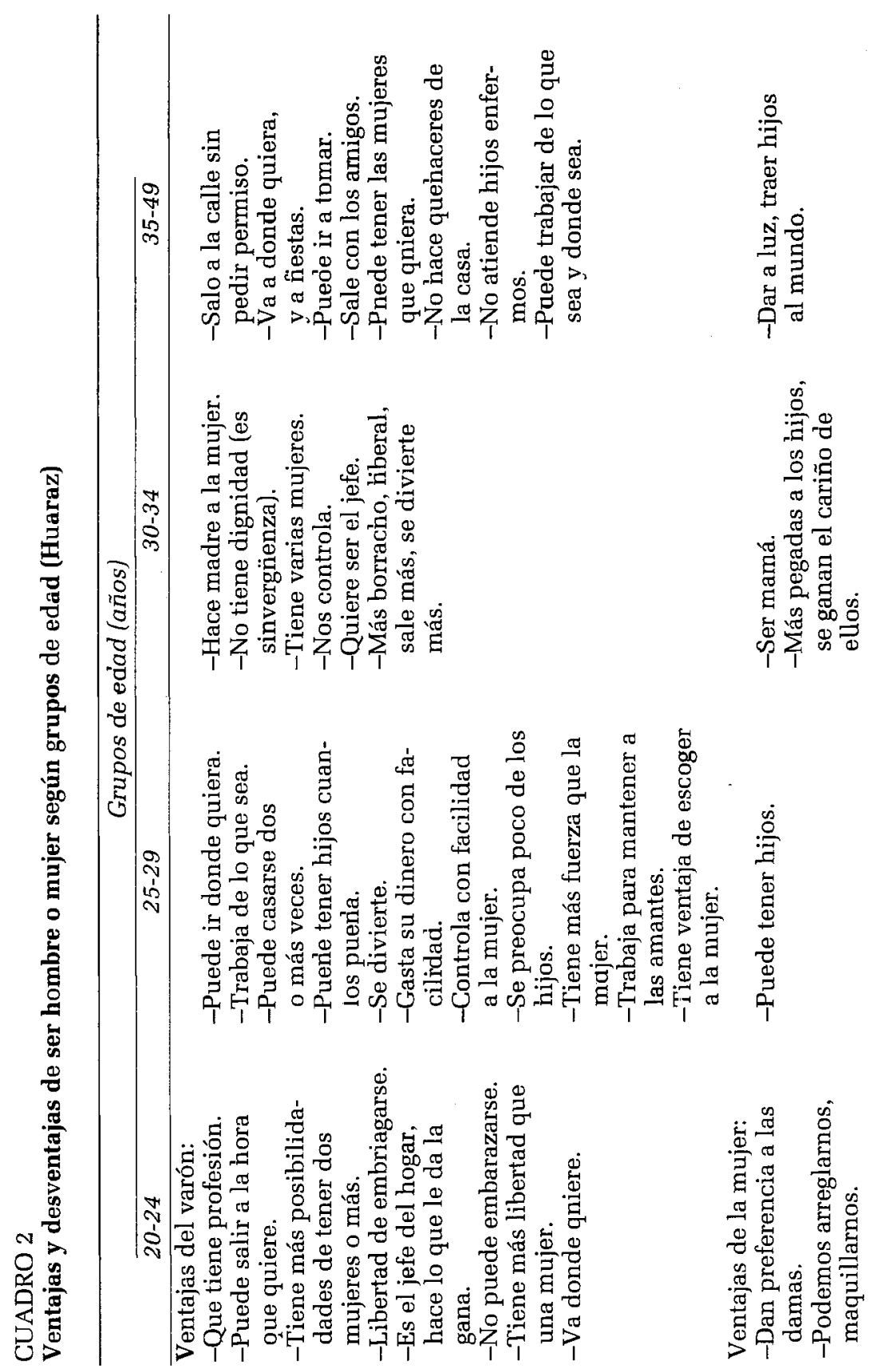


ESTUDIO COMPARATIVO DE MUJERES DE TRES CONTEXTOS DEL PERÚ 179

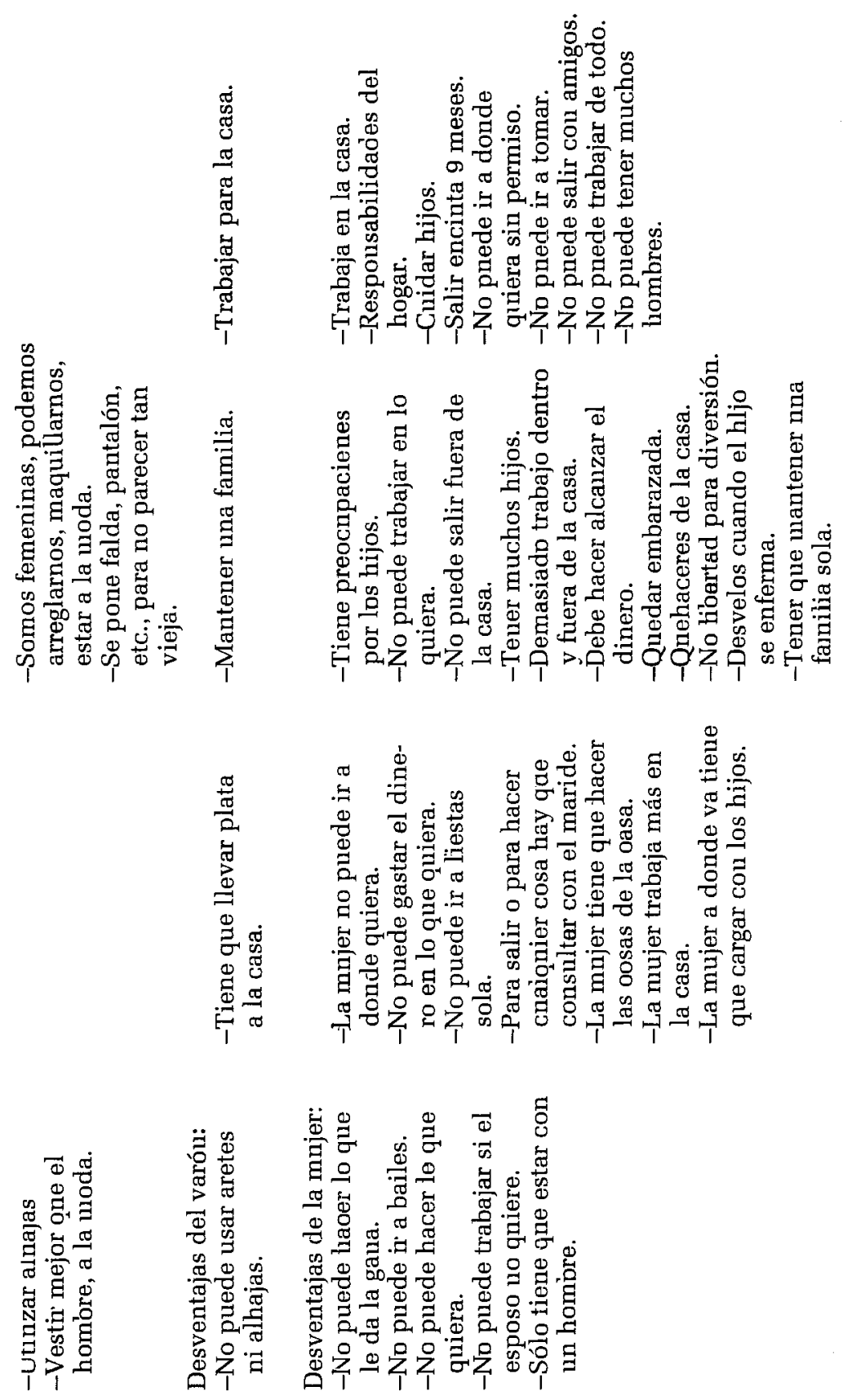




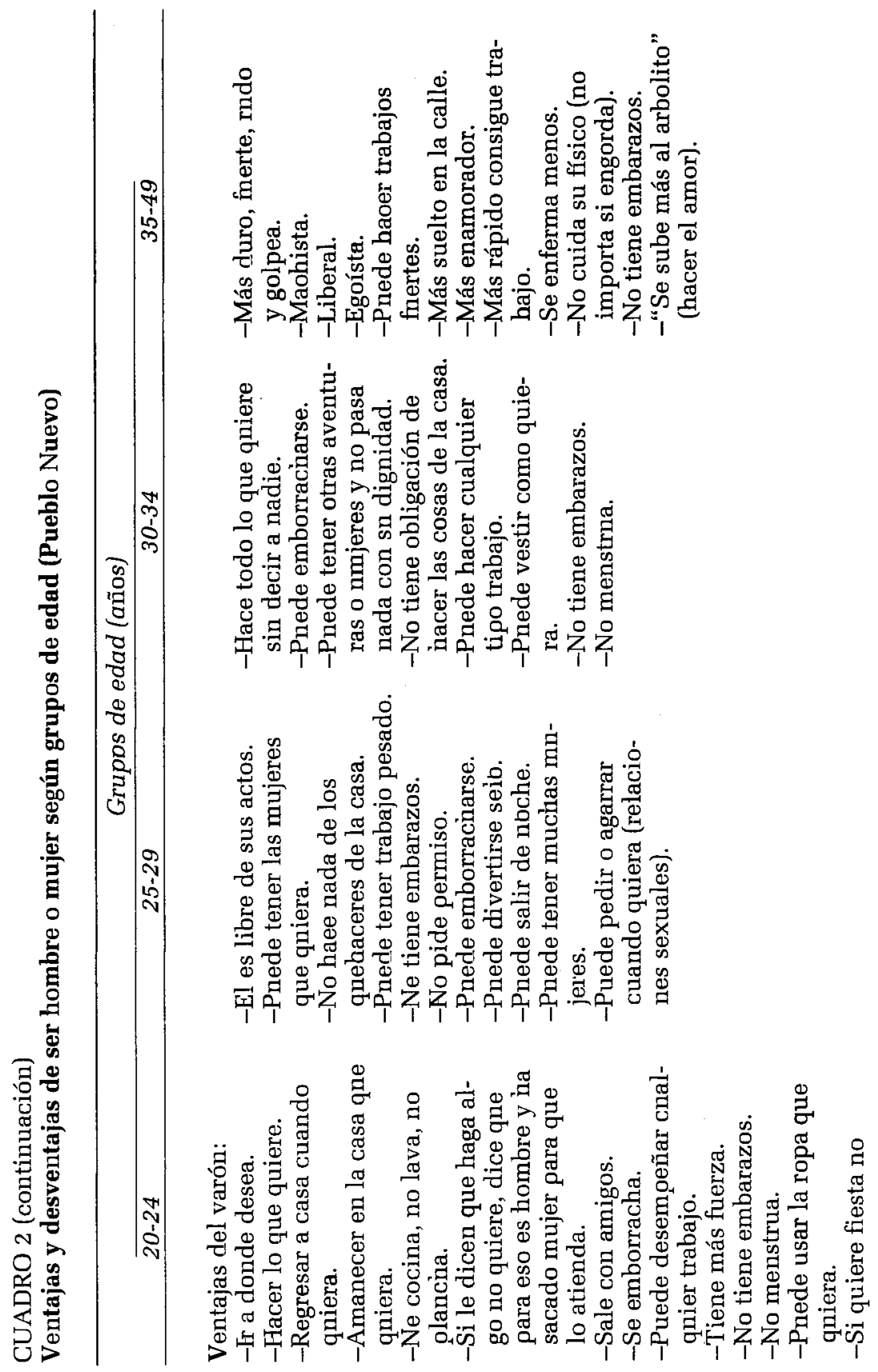


ESTUDIO COMPARATIVO DE MUJERES DE TRES CONTEXTOS DEL PERÚ 181
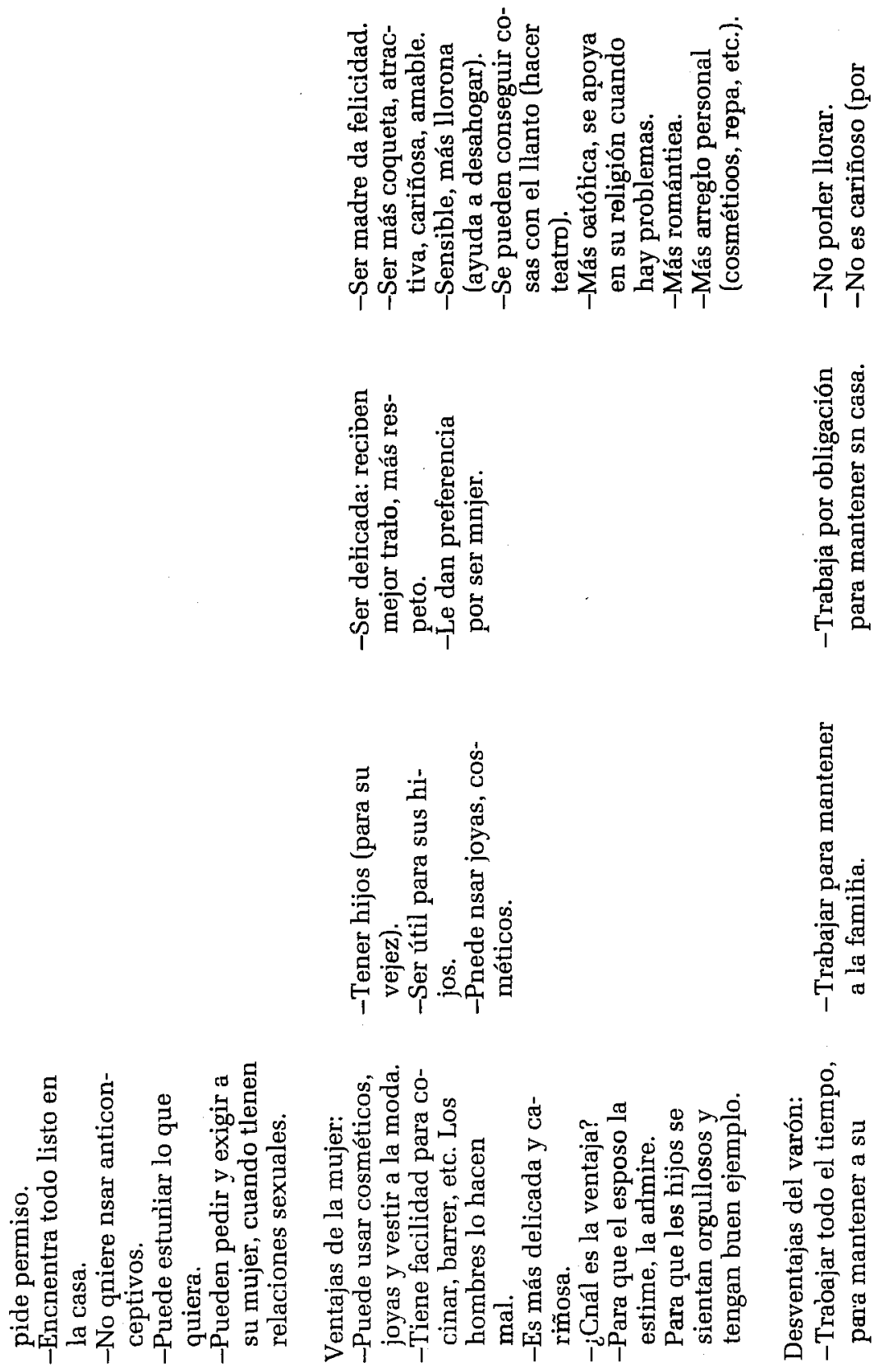


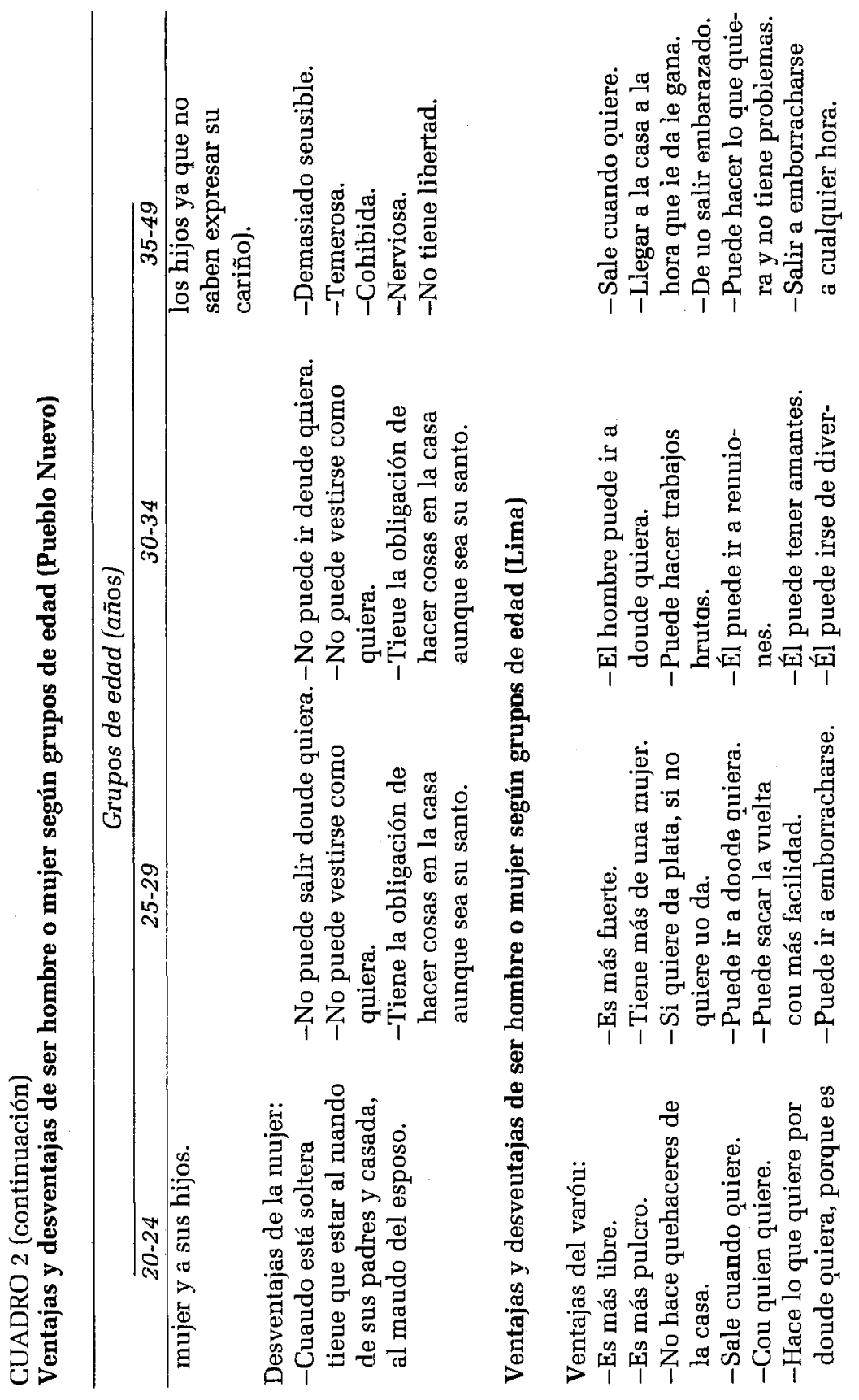


ESTUDIO COMPARATIVO DE MUJERES DE TRES CONTEXTOS DEL PERÚ 183
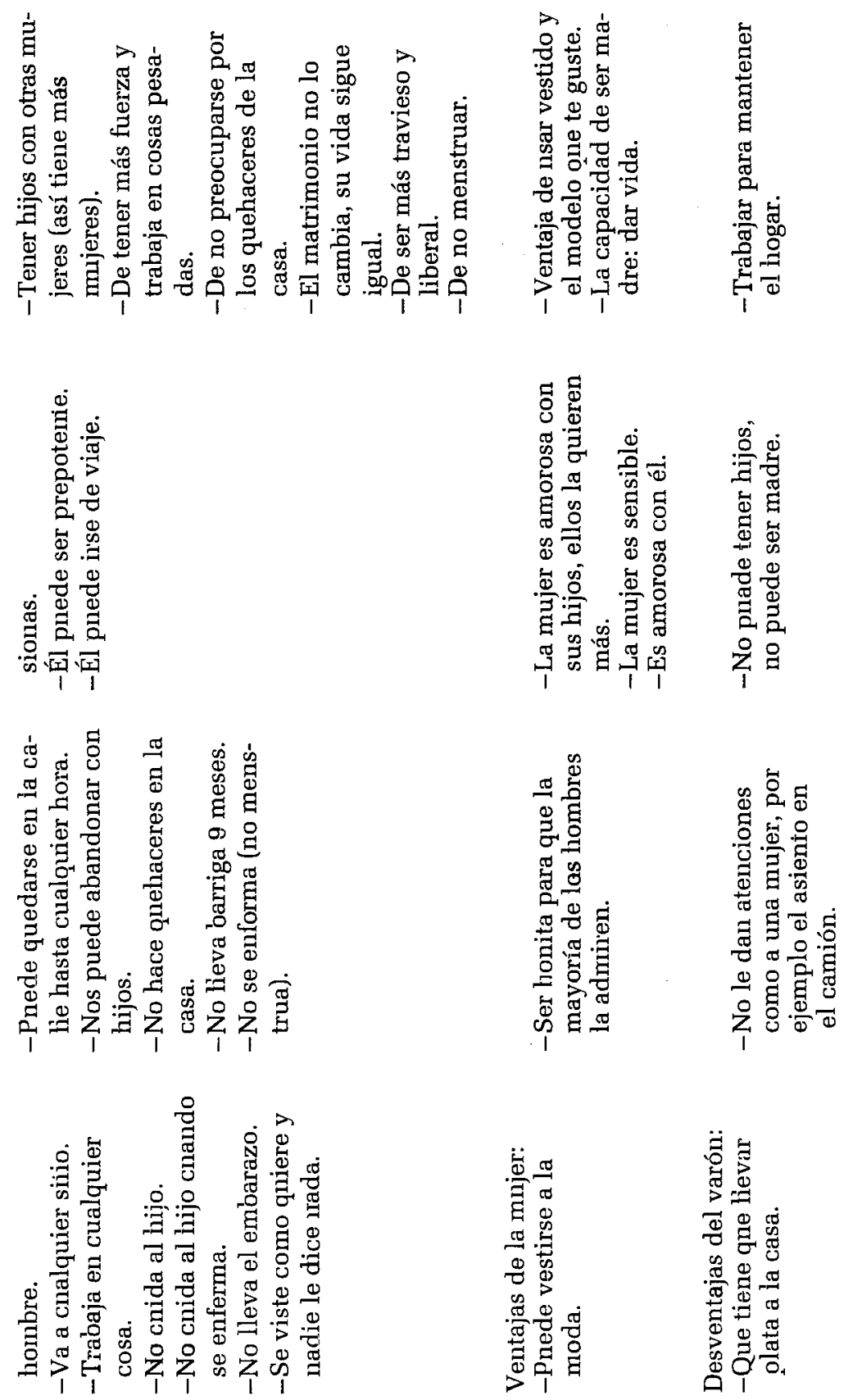

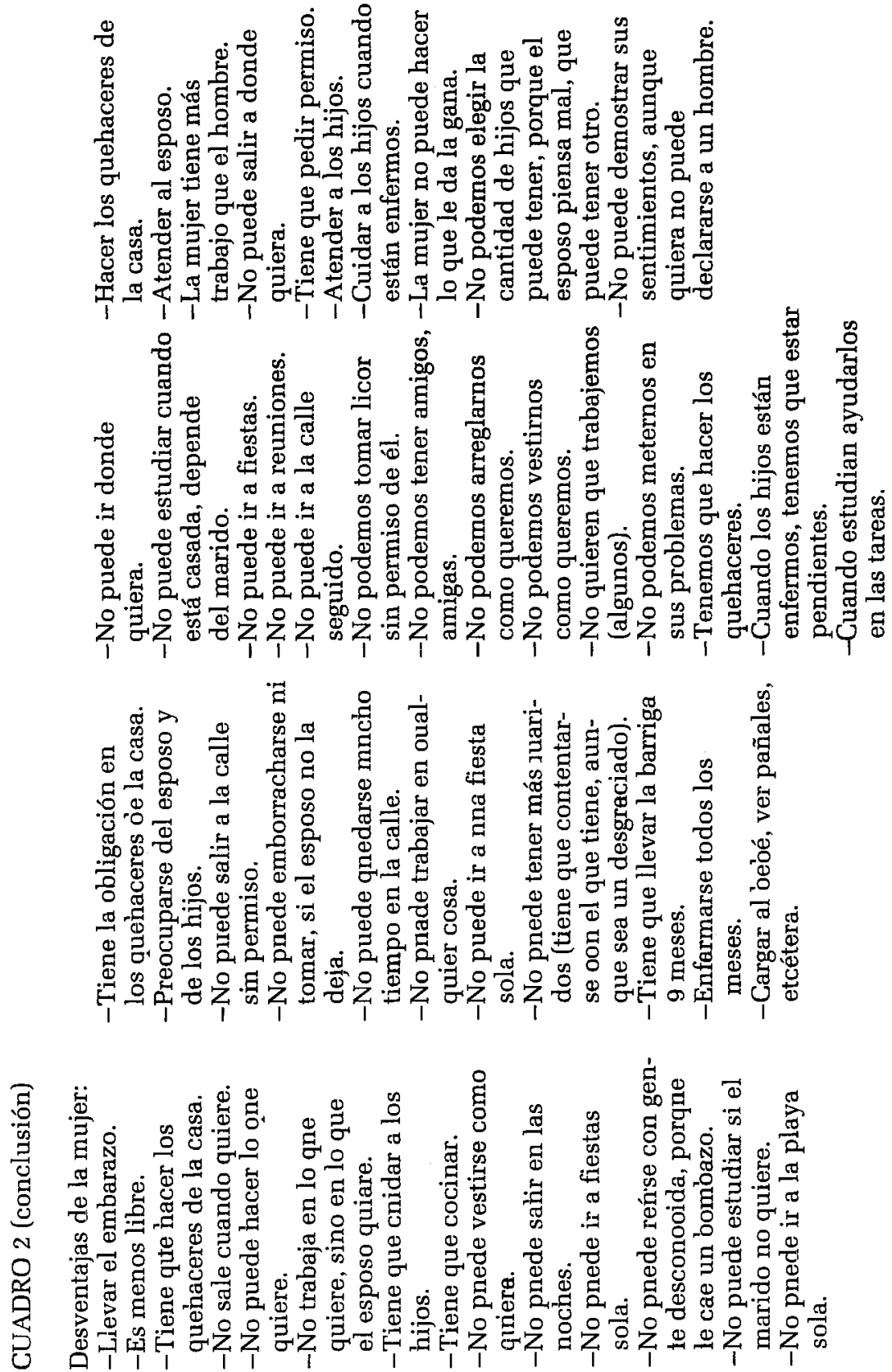
nante, la mujer como esposa o como amante pasaría en esta reflexión ideal a un segundo lugar. Los celos del esposo frente al tiempo que ella le dedica a sus hijos se compensan en un mayor control ejercido por él para que ella dé buen cumplimiento a su función de madre.

La realización de la mujer en el trabajo no es percibida; el trabajo es solamente una forma de obtener un beneficio económico para mejorar la situación de los hijos. En contextos más urbanos (Huaraz) es visto como una forma de lograr independencia frente al esposo, ya que les da la posibilidad de "decidir sobre su dinero y comprar lo que queremos". Siendo el trabajo sólo un medio, es explicable que esté supeditado a la aceptación del esposo.

Sin embargo, parece existir una creciente conciencia de la importancia del trabajo femenino. Ello contrasta, según opinión de sus compañeras, con la renuencia del varón a asumir alguna tarea doméstica. Es interesante resaltar que cuando el esposo decide ayudar puede inclusive recibir el rechazo social:

...mi esposo lavaba pañales río arriba para que nadie lo vea, tú no te alcanzas, yo te ayudo (decía). Saco largo le decían (Carmen, 40 años; Pueblo Nuevo).

El matrimonio, en estos contextos, parece reforzar la subordinación de la mujer al varón y revela muy pocos cambios hacia una relación más igualitaria y democrática. El "reino de la mujer" sigue estando reservado para ella, el feminismo está aún por ser descubierto en estos sectores sociales.

Expectativas y realidades de la vida en pareja

Con respecto a este punto pudimos ver en los talleres que lo que más valoraban las mujeres en su relación de pareja era la satisfacción sexual y el amor. Los grupos mayores destacaron también la satisfacción de una vida juntos en la que hubiera comprensión, comunicación y confianza. Esto se relaciona con el hecho de compartir diversión o trabajo con sus compañeros.

Por el contrario, lo que menos les gusta a las mujeres en su relación de pareja son las peleas y la embriaguez vinculadas con el maltrato y la violencia. Las relaciones sexuales no satisfactorias también fueron destacadas por muchas mujeres, sobre todo por las más jóvenes. Relaciones en las que se las obliga, o que involucran violencia y que no causan placer, o aquellas en las que el marido se muestra indiferente y poco comprensivo. 
Muchas mujeres mencionaron otros obstáculos para una buena relación, tales como el que el marido sea irresponsable o se emborrache, sea infiel o demasiado celoso.

Cuando se preguntó con respecto a la violencia ejercida por el esposo pudimos ver que ésta estaba vinculada con la bebida. Muchas manifestaron que los maridos les pegaban principalmente cuando estaban borrachos y que esto ocurría con más frecuencia los fines de semana. En cuanto a los motivos de la violencia las mujeres los dividieron en dos, aquellos que son injustificados, como:

Por que "es malo; o por "aburrido"; "por gusto" o porque "llegó borracho". También se producen situaciones violentas cuando el marido es infiel, es decir el marido las agrede cuando "se le calienta la cabeza".

También expresaron otras situaciones violentas, en las que está implícita una justificación más o menos velada a la actitud del varón:

— Porque "ella es mañosa"

- Porque ella "no hace las cosas de la casa"

- Porque "la han visto chismeando"

- Porque "maltrata a los hijos"

$\mathrm{Y}$ a veces simplemente porque "no le hace caso a su marido".

Es decir para muchas mujeres si la esposa no cumple con todas sus obligaciones o no le hace caso al marido merece que éste "se haga respetar", incluso recurriendo a la violencia.

La violencia y el maltrato, por lo general, van acompañados de insultos, según las participantes de los talleres, los hombres utilizan correas, palos y los puños durante la agresión. La reacción de las mujeres frente a la agresión es llorar y gritar y en algunos casos defenderse y tirar cosas. Luego él pide disculpas o no lo hace y "todo sigue normal". Las mujeres de los talleres, en general, no vieron la separación del cónyuge como una solución ante el problema de la violencia.

La mayoría de las participantes en Pueblo Nuevo supusieron que ellos en su mayor parte no reaccionan con violencia ante la negativa de ellas a tener relaciones sexuales. Sin embargo, las relaciones sexuales forzadas se convirtieron en un tema de discusión, vinculándolas principalmente con la embriaguez de los cónyuges.

La violencia parece muy frecuente en el nivel de los talleres, no obstante, en las historias de vida, sólo dos de las 20 mujeres entrevistadas en Pueblo Nuevo manifestaron que el marido les pega, y una dijo que antes le pegaba pero ya no lo hace más. 
Sin embargo, en Huaraz encontramos varios testimonios donde las mujeres relatan sus experiencias y su rechazo a la violencia ejercida por sus maridos:

... Ahora tengo inflamación al ovario y infección, un día llegó tomado, de su querida venía, me tiró patadas, al hospital tuve que ir (Igima, 25 años; Huaraz). ellas:

La bebida lleva a la pareja a situaciones insoportables para

Nos peleamos mucho, mucho toma, cuando discutimos yo duermo con mis hijos, a veces una mujer se aburre cuando toma el hombre, no se puede ni estar, apestan. Para en la calle, vagando nomás, yo cocino, atiendo a mis hijos, lavo, todo yo nomás. Nunca me ha ayudado, cuando estoy sana dice que porque me va a ayudar. Hay hombres que sólo le gustan estar encima de la mujer, en la nochecita nomás te llama, yo de castigo tampoco duermo con él (Maritza, 22 años; Huaraz).

Los celos de la pareja es otro factor que incita a la agresión y a la violencia, esta desconfianza puede estar motivada o no, llegándose a veces a producir reacciones extremas:

Él se porta con exigimiento a veces me pega, se acuerda que tengo mi pasado. Mi esposo es bueno, no viene mareado, a veces me pega cuando se acuerda de mi pasado. Después todo bien (Benita, 32 años; Lima).

Según podemos ver en la cita anterior, se llega a justificar la violencia del esposo como castigo a un pasado sexual que, según ella, no debió haber existido.

Por el contrario la falta de interés del hombre en ellas y la presencia de otras mujeres también los lleva a maltratarlas:

Al principio todo bien, hace 5 años hemos estado feliz. De tomar no toma, pero se consiguió otras mujeres, de ahí ya tarde llegaba, a las 11 en la noche llegaba, con otras ha estado, no me ha maltratado pero cuando se ha vivido con mi hermana ahí sí, enamorados andaban, así salían, paseaban, por bosques andarían, por hoteles andarían (Celestina, 31 años; Huaraz).

Con respecto al comportamiento sexual de la pareja, sólo algunas de las mujeres entrevistadas declararon al respecto, encontrándose un mayor hermetismo en el contexto andino (Huaraz). En muchos de los testimonios recogidos podemos ver la sumisión de la mujer y cómo reprime sus deseos: 
Cuando él quiere estar conmigo y yo no quiero, me dice que he estado con otro y tengo que hacerlo para cumplir; y si yo quiero calladita, él puede pensar que soy una mujer que le gusta estar con el marido. Al principio tenía vergüenza de desnudarme recién cuando he tenido mi segundo hijo lo hice, ahora más confianza (Sara, 23 años; Pueblo Nuevo).

Normal es, yo me quedo quietita, eso de poses no es normal, ahora ya hay más confianza, al principio me quedaba quietita, no quería (Leticia, 32 años; Pueblo Nuevo).

Cuando quiere tener relaciones me avisa, a veces estamos de acuerdo, a veces me despierta no más a la hora que llega, siempre tengo que hacerlo sino dice que tengo otro (Consuelo, 37 años; Pueblo Nuevo).

Yo por todas partes quiero escaparme. El me dice "tú no pareces mujer todo sufriendo haces" por mi esposo yo tengo que correrme. El dice "cuando yo quiera vas a salir encinta, tú eres mi mujer". El es más caluroso, quiere estar conmigo, sino estoy con él me dice "yo tampoco te voy a dar plata pues" (Juana, 32 años; Lima).

La ignorancia unida a experiencias sexuales poco satisfactorias, conducen a actitudes como la siguiente:

A mí no me gustan las relaciones, siempre por cumplir, una es la esposa... me hacen daño, me da dolor de cabeza, malestar de cuerpo, por eso mi esposo no me exige estar con él. Por mi voluntad no quiero estar con el hombre, él me dice "si te hubiera tocado un hombre exigente ya te hubiera matado, a ti no te gusta estar con un hombre". Yo he ido al médico pero nunca le he consultado por vergüenza, será de naturaleza, o ¿como será? El me dice "mejor me voy a conseguir otra mujer" pero no tiene... (Carmen, 40 años; Pueblo Nuevo).

El temor de salir embarazada también es un argumento a ser tomado en cuenta en este punto, ya que influye en el comportamiento sexual de la pareja, limitando las posibilidades de un desarrollo más pleno y libre como veremos a continuación:

El es bien exigente, es bien ardiente, yo me siento aburrida, fastidiada. Después de mi primera hija yo era otra, ahora me he vuelto más bien fría, no tengo deseo, él ya no me siente fogosa, ¿qué será?, el miedo a tener hijo, ya no quiero salir embarazada (Chabela, 25 años; Lima).

Las reacciones sexuales violentas también son mencionadas en algunos de los testimonios recogidos y como veremos a continuación hay algunas que encuentran la forma de hacerse respetar:

Me dio miedo, el hombre es bien malo, a la fuerza, yo no quiero, yo no quiero estar con él, relaciones sexuales, muchos hijos no se puede tener me ha dicho doctor. Mi esposo toma mucho, me exige estar 
con él, una vez me ha pegado. Yo embarazada, me tiró con la mano sopapo (cachetada), yo le tiré con madera, con un palo en la cara, ya nunca más. Cuando la mujer le gana al hombre ya le tiene miedo (Cecilia, 42 años; Huaraz).

Por el contrario hay pocas mujeres que se encuentran satisfechas con su vida sexual.

Actualmente nos complementamos en la vida diaria y en la intimidad, no me obliga, cuando yo no quiero se da la vuelta y ya, hacemos si dos o tres veces por semana, cuando estoy con la regla ahí no (Juana, 32 años; Pueblo Nuevo).

La búsqueda de su propia satisfacción sexual no parte de las mujeres, se logra más bien cuando la pareja es lo suficientemente amplia de criterio como para propiciarla:

El me insinúa que ya no soy como antes, creo que el corrido de los años hay más confianza, ya tenemos 21 años de casados. Me ha comprado libros para que vea que no me engaña, él trata que yo quede siempre satisfecha, por mí no lo hago sino por ti, me dice (Mirna, 41 años; Pueblo Nuevo).

La evidencia anterior revela que el matrimonio para las mujeres de estos contextos populares refuerza en la mayoría de los casos su subordinación al varón, que sus sueños de matrimonio ideal no se cumplen, y que la función del matrimonio tiene más que ver con proveer un contexto que haga económicamente viable la procreación que con la satisfacción de sus deseos de afecto, seguridad y sexualidad placentera. Asimismo existe un aparente fatalismo atribuido a la naturaleza inmutable del hecho de ser varón o mujer y un bajo nivel de autoestima atribuible al hecho de ser mujer con independencia de sus circunstancias educativas y económicas individuales. En suma, que los cambios observados a nivel agregado en el comportamiento demográfico de estos grupos poblacionales, tienen poco que ver con un cambio cualitativo de la relación de pareja respecto a sus roles, valoraciones y normas y más bien con ajuste a factores económicos y a la crisis de oportunidades que hace no menos de dos décadas afecta a estos sectores sociales del país. Sobre esta tesis regresaremos en la sección sobre anticoncepción. 


\section{Lactancia materna}

La lactancia materna no es únicamente un proceso natural vinculado a la maternidad; sus prácticas están dentro de patrones culturales y por lo tanto están cargadas de valores y normas. A nivel agregado, esta variable intermedia de la fecundidad revela poca variación en la proporción de madres que declaran haber dado de lactar a su último hijo según zonas geográficas, nivel educativo o grado de urbanización, estando muy generalizada. Sin embargo, las encuestas demográficas recientes revelan diferencias notables en su duración y frecuencia. Así, tenemos que en áreas rurales la duración promedio de la lactancia para el último nacido vivo fue de 20 meses, en tanto que para las mujeres urbanas fue de sólo 14.2 meses en promedio. Entre las mujeres analfabetas (en su mayoría de residencia rural), la lactancia tuvo una duración promedio de 22 meses, mientras que entre las mujeres con educación secundaria o superior ésta fue de 14.8 y 10.3 meses respectivamente. Asimismo, la frecuencia de la lactancia (estimada por la proporción de mujeres que dieron de lactar a su hijo seis veces o más en las últimas 24 horas) presenta diferencias notables; $91 \%$ de las mujeres rurales daban de lactar seis o más veces al día, en tanto que $74 \%$ de las madres limeñas observaban esta recomendable práctica.

Si bien es cierto para la mayoría de las mujeres en los tres contextos estudiados, la lactancia materna es vista en un sentido positivo, como el ejemplo principal de dedicación de la madre al bienestar de su hijo, también encontramos, en mucho menor medida, la presencia de la modernidad en declaraciones alusivas a la vergüenza de dar de mamar en público o a la falta de libertad para cumplir con el trabajo. En los contextos más urbanizados el rol de la mujer-madre que fuera el principal, casi el único en la cultura tradicional, empieza a ceder espacio a la percepción de otros roles como importantes: la mujer como pareja sexual, la mujer trabajadora. Esta nueva visión de la mujer expresada principalmente en la importancia de la educación de las hijas en la familia de origen, se refleja también en las prácticas vinculadas a la sexualidad y la reproducción.

En los talleres en los que las mujeres manifestaron sus concepciones ideales en relación con la lactancia, encontramos que la principal razón percibida por las mujeres a favor de la lactancia materna estaba vinculada a la salud del niño. La idea de que la leche materna protege al niño de enfermedades fue enfatizada repetidamente.

La segunda razón a favor de la lactancia materna fue de tipo económico, lo cual es comprensible en un contexto deprimido 
como el peruano. Otras razones de tipo utilitario fueron mencionadas tales como la comodidad, el ahorro de tiempo y energía de la madre.

Es interesante destacar que la idea de la lactancia como un método para controlar la fecundidad fue destacada sólo en el medio rural. En las historias de vida únicamente dos personas mencionaron la vinculación entre la lactancia y la concepción.

Tres años le he dado a todos porque dejando de mamar sale uno embarazada, mi suegra me aconsejó, con la regla también me cuidaba, cada hijo me venía de sorpresa (Elena, 26 años; Pueblo Nuevo).

En la mayoría de los casos la lactancia es vista como un "deber" incuestionable, necesario para el desarrollo de un niño sano. Negarle la leche materna al niño genera sentimientos de culpa que hacen que la mujer no vuelva a repetir su error.

A la mayor no le di de lactar porque como era primeriza, no me había formado bien el pezón, no tenía mucha leche y media floja era para dar la teta, por eso ha crecido media raquítica dice mi suegra. En ese momento no sabía el daño que le hacía... A los 3 meses salí embarazada de la segunda, 2 años le di pecho, tenía bastante leche, es una muchachota... (Consuelo, 37 años; Pueblo Nuevo).

Son pocas las que sostuvieron una actitud de rechazo ante esta práctica común. Las razones fueron vergüenza de dar de mamar en público, desagrado y deseo de conservar su propio cuerpo, como podemos apreciar los valores que entran en juego con respecto al rol de la mujer son distintos, reemplazándose y reordenándose los símbolos en torno a la sexualidad.

El tiempo de duración de la lactancia varió de un contexto a otro. En el área rural se señaló que lo ideal era dar de mamar al niño hasta el año, mientras que en la capital del país el tiempo ideal indicado fue de siete meses. La mayoría de las entrevistadas dieron leche materna a sus hijos por más tiempo del que declararon como ideal, encontrándose un corte generacional en Lima, ya que las mujeres de los grupos más jóvenes no sobrepasaron el año de lactancia, mientras que la mayoría de los grupos mayores sí lo hicieron.

Resumiendo, los cambios culturales parecen no haber afectado a la proporción de madres que dan de lactar a sus hijos, pero sí a su duración y frecuencia. Esta práctica es más corta y menos frecuente entre las madres más jóvenes de los contextos más modernizados, entre los que los roles de pareja y de trabajadora van lentamente restando importancia al rol exclusivo de la maternidad. 


\section{Anticoncepción}

La planificación familiar y la anticoncepción constituyen aspectos cruciales para un mejor control de la vida sexual y reproductiva de la mujer en la sociedad moderna. Sin embargo, innumerables estudios recientes han encontrado diferentes niveles de conocimiento y uso de métodos anticonceptivos entre las mujeres de sectores populares del país. Según la encuesta de prevalencia más reciente (ENDES, 1991-1992), pese a un conocimiento alto y generalizado de los métodos anticonceptivos (96\% declara conocer un método y $89 \%$ señala correctamente la fuente de suministro del método), el uso de métodos eficaces fluctúa entre $40 \%$ de las mujeres unidas urbanas y $\mathbf{1 5 . 5} \%$ de estas mujeres en el medio rural. Las diferencias son aún más notorias según el nivel educativo de la mujer; entre las analfabetas en unión la prevalencia de métodos eficaces (esterilización, DIU, pildoras, condón y métodos de barrera) es de sólo $11 \%$, entre las que tienen primaria completa sube a $24 \%$, es de $40 \%$ entre las mujeres unidas con secundaria completa y llega a $48 \%$ entre las que tienen educación superior. Por lo tanto, el promedio nacional de prevalencia de métodos eficaces de $33 \%$ oculta significativas diferencias. Es también notable que una gran proporción de usuarias (59\% entre las MEF unidas) siga utilizando los métodos tradicionales (ritmo y retiro); más de un $44 \%$ del total de mujeres unidas usan algún método.

En este estudio nos interesa profundizar en los aspectos culturales y valorativos relacionados con la planificación de los embarazos y el uso de anticonceptivos. Es decir, abordar los aspectos cualitativos de la anticoncepción, ubicándola en su entorno cultural y generacional, pues estos aspectos no pueden desprenderse de las encuestas de prevalencia comunes. Ello puede permitir entender las razones que explican los grandes diferenciales en la práctica anticonceptiva mencionados anteriormente.

\section{Anticoncepción antes de la unión: información y conocimiento}

La información que recibieron las mujeres con respecto a métodos anticonceptivos antes de la unión fue realmente muy limitada. La mayoría de ellas no sabían absolutamente nada sobre la posibilidad de evitar un embarazo no deseado y más aún este tema parecía encontrarse fuera de su área de interés.

En Pueblo Nuevo es donde se encontró un mayor conocimiento de los métodos, es así que de las 20 mujeres entrevistadas cinco habían oído hablar algo con respecto a la anticoncepción 
antes de su primera relación sexual. De estas cinco, tres pertenecían al grupo de las más jóvenes. Este inesperado resultado se debe a que en este poblado rural ha existido un activo programa de planificación familiar desde comienzos de los ochenta.

La familia y las amigas fueron las principales fuentes de información. Muchas otras oyeron a sus hermanos o aprendieron de las amigas mayores:

Antes de casarme escuchaba que usaban la pildora, las ampollas pero no sabía cómo se usaban (Elizabeth, 24 años; Pueblo Nuevo).

Como podemos apreciar el conocimiento de métodos anticonceptivos en esta etapa de la vida es bastante superficial reduciéndose solamente a un haber oído hablar del tema.

En la parroquia de Guadalupe cuando estaba en cuarto año de secundaria nos pasaron una cinta de cómo se tienen los hijos, para cuidarse con el ritmo, con los días, yo había escuchado de las amigas pero no entendía bien. A mi mamá nunca me atrevía a preguntarle... (Julia, 20 años; Pueblo Nuevo).

Es importante destacar el rol que cumple la pareja como fuente de información en este tipo de temas, ya que en el fondo la mujer espera la iniciativa del varón, existiendo un orgullo implícito en afirmaciones como "... él me cuida..." presentes en muchos de los testimonios.

En los casos restantes sólo dos personas manifiestan abiertamente no haber tenido ninguna información. El resto de las mujeres se sintieron cohibidas de tocar el tema, ya que el conocimiento de métodos contraceptivos a temprana edad implica una cierta libertad sexual que ellas no estaban dispuestas a admitir.

En el caso de Lima, ninguna de las entrevistadas afirma haber conocido algo sobre métodos anticonceptivos antes de la unión. Nueve de las mujeres manifestaron no haber tenido ningún conocimiento al respecto y el resto no rindieron un testimonio claro que nos permita afirmar que sí conocían.

En la mayoría de los casos la ignorancia y el temor se unen creando un rechazo en la usuaria potencial, como analizaremos más adelante.

\section{Anticoncepción antes de la unión}

En los talleres, las mujeres de todos los grupos de edad de las tres localidades manifestaron que la chica de la historia sin final no 
usa anticonceptivos. Tan sólo dos mujeres pertenecientes al grupo de las más jóvenes de Huaraz dijeron que tal vez la chica se cuide con algún método natural como el ritmo o el retiro.

Tanto en Pueblo Nuevo como en Huaraz encontramos una diferencia generacional que se refleja en la opinión de las mujeres con respecto al conocimiento de los métodos. En Pueblo Nuevo las más jóvenes manifestaron que la chica "sí sabe, pero no se cuida", mientras que los grupos mayores consideraron que "no sabe cómo cuidarse", aunque reconocieron que en la actualidad las chicas tienen más información. Esta idea está respaldada por las historias de vida en las que como vimos anteriormente, son las más jóvenes las que tienen más información sobre el tema. En Huaraz, por el contrario, fueron las mayores las que afirmaron que la chica sí sabía sobre los métodos, que ahora se les informa en el colegio; mientras que en los otros grupos fue mayoritaria la opinión de que la chica no sabe, ya que según dijeron las jóvenes tienen vergüenza de preguntar y por lo tanto no saben nada. Es importante destacar que en los talleres estuvo presente la idea de que la mujer es "débil" y "no piensa". En Lima, la gran mayoría pensaba que la joven sí conocía de anticonceptivos, pero que no se cuidaba hasta después de 2 o 3 hijos pues "es necesario pasar por la experiencia", "los esposos se oponen", y "el primer regalo del matrimonio es el hijo".

Estas opiniones reforzaron la idea de que el uso de anticonceptivos, al menos antes de la unión, es un problema que va más allá del conocimiento, ya que involucra una percepción valorativa de cuál debe ser el papel y el comportamiento de la mujer en la sociedad. Estos patrones culturales que explican el temor de las mujeres al rechazo social, tienen que ser tomados en cuenta en cualquier programa de comunicación o acción en población.

En cuanto a las historias de vida podemos ver que son pocas las que usan anticonceptivos antes de la unión. En Huaraz, de las nueve que mantuvieron relaciones sexuales antes de la unión sólo dos declararon haber empleado algún método anticonceptivo (el ritmo y el preservativo). Una de ellas manifestó haber usado mal el método, pues ya se quería casar, y la otra, como vimos anteriormente, fue abandonada por el novio. En Pueblo Nuevo, de las 19 que mantuvieron relaciones sexuales antes de la unión formal, sólo cinco usaron algún método para impedir la concepción. Es importante resaltar que en la relaciones previas a la unión es el hombre el que asume la iniciativa en el uso del método, predominando los métodos masculinos (preservativo, coitus interruptus, etcétera). Incluso en el caso del ritmo muchas declaran que son ellos los que cuentan los días y finalmente deciden cuando están 
fuera de peligro. Reforzando lo señalado, es sorprendente comprobar cómo en Lima ninguna de las 14 que mantuvieron relaciones sexuales antes de la unión usó algún método anticonceptivo, saliendo consecuentemente casi todas ellas (13) embarazadas.

Este patrón de participación masculina en la anticoncepción previa a la unión contrasta con la actitud del esposo dentro de ésta, en la que, como veremos más adelante, deja a la esposa la responsabilidad de "cuidarse" pensando que en última instancia se trata de un problema femenino.

\section{La anticoncepción en la vida conyugal. Conocimiento}

En los talleres grupales se preguntó a las mujeres por el significado de la planificación familiar. Se consideraron respuestas válidas a aquellas que mencionaron a la regulación de la fecundidad como lo central tales como "decidir cuántos hijos tener", "no tener muchos hijos" o "cuidarse con anticonceptivos". Entre las respuestas consideradas inválidas estuvieron aquellas que aludieron al bienestar familiar o a nociones poco precisas tales como "planear el futuro de la familia", "alimentar a los hijos ", etcétera. En particular se encontró que el nivel de conocimiento era generalizado en Pueblo Nuevo en todas las generaciones, alto en Lima, pero sólo entre las generaciones más jóvenes, y más bajo en Huaraz en casi todos los grupos de edad. Entre las mujeres mayores de 30 años se confundía el tema de la planificación familiar con aspectos más generales del bienestar familiar, tales como "ser buena con los hijos " o "ser bondadosa y no tener problemas" (Huaraz), o con "trabajar en la casa" y "atender al esposo y hacer la limpieza" (Lima). El origen andino de muchas migrantes a Lima y el entorno tradicional de una ciudad como Huaraz condicionan para las generaciones mayores un desconocimiento casi total del tema:

Diez hijos he tenido, nunca he tomado nada. En Lima he escuchado "como animales se tienen hijos" pero yo ya nada. Ya se me va mi regla y hace tiempo no tengo esposo... Ahora ponen ampolla obligado, dicen, jcómo el gobierno va a mantener y criar bastantes hijos si no hay sueldo ni trabajo! (Sra. Sánchez, 50 años; Huaraz.)

En cuanto al conocimiento sobre la efectividad de los anticonzeptivos encontramos que la mayoría de las mujeres declara un zonocimiento teórico sobre los mismos y que las de mayor edad in los tres contextos creen que los métodos tradicionales (lavados, ritmo y retiro) son los más efectivos. Por el contrario, entre 
las más jóvenes hay una clara percepción de que la ligadura y el DIU son los de mayor eficacia.

En relación con su accesibilidad, la mayoría de las participantes en los talleres opinó que la píldora era el método más fácil de encontrar, sobre todo en Pueblo Nuevo, seguida de las inyecciones, el preservativo y los lavados. Esta última fue la opinión de las mujeres de Lima que posiblemente se refirieron a facilidad de uso antes que a accesibilidad.

Finalmente, al indagar sobre facilidad de uso, algo más de un tercio respondió que los inyectables eran más convenientes, sobre todo según las informantes de Pueblo Nuevo y Huaraz. Esto parece deberse no tanto al efecto duradero de los anticonceptivos inyectables, pues el DIU ciertamente ofrece una mayor duración, sino a la mayor familiaridad con los inyectables por parte de esta población. En segundo y tercer lugar se mencionaron a los ciclos orales y al ritmo. Con respecto al costo, no hubo diferencias generacionales relevantes señalándose a la pildora, la ligadura y al retiro como los métodos de menor costo.

Algunas mujeres no acuden a los programas de planificación familiar existentes y más bien tratan de acudir a un médico privado o a las redes comerciales, en cuyo caso el costo sí es importante, como podemos ver en algunas historias de vida:

... ligar es muy caro, como cinco millones, si costase más barato lo haría (Elena, 26 años; cuatro hijos; Pueblo Nuevo).

... Después de mi segunda hija empecé a tomar Nordete-21, me la recomendó la farmacéutica, pienso ponerme la $\mathrm{T}$ de cobre cuando tenga plata... (Consuelo, 25 años; Pueblo Nuevo).

... estaba tomando pastillas, Triquilar. Fui a la farmacia y pregunté, me recomendaron esas, cuatro meses estuve usando, no seguí porque habían subido de precio, un mes dejé de tomar y ya no tomó más (Meche, 24 años; Lima).

Según podemos apreciar en los testimonios anteriores la farmacia tiene gran importancia como fuente de información en relación con la planificación familiar, influyendo en las decisiones que las mujeres toman sobre el método a usar.

Los problemas económicos pueden interferir también con el buen funcionamiento del método, dándose un uso incorrecto del mismo:

... A veces no tenía para comprar (la pastilla) y la empezaba a tomar después de ocho días de mi regla, creo que por eso puede haber fallado. No uso la de la posta, prefiero comprar, tomaba Microginón 28... (Elizabeth, 24 años; Pueblo Nuevo). 
Como se aprecia existen importantes lagunas e incongruencias en el nivel y tipo de conocimiento de los anticonceptivos, que revelan la necesidad de una mayor difusión del significado de la planificación familiar y de la efectividad y costo comparativo de los diferentes métodos. A continuación analizaremos las ventajas y desventajas percibidas por estas mujeres respecto de cada uno de los métodos anticonceptivos.

\section{Ventajas y desventajas de los anticonceptivos}

En los talleres se abordó también el tema de las ventajas y desventajas percibidas sobre cada uno de los métodos anticonceptivos. En el cuadro 3 se presentan los resultados distinguiendo por grupo de edad pero no por localidad, pues entre éstas no hubo diferencias significativas.

En relación con la pildora, la principal ventaja señalada por todos los grupos de edad es la de su efectividad, el que permite tener relaciones "todos los días" y en menor medida su efecto regulador de la menstruación. Entre sus desventajas, sólo las más jóvenes señalaron correctamente el inconveniente de tener que tomarse todos los días. Incorrectamente todos los grupos de edad señalaron como inconveniente el hecho de que altera el sistema nervioso; "ataca los nervios", "cambia el carácter", "choca al sistema nervioso" fueron frases frecuentes de las mujeres de todas las edades y contextos en los talleres. Además, muchas señalaron que su uso engorda, y que da dolor de cabeza, dolor vaginal y otros supuestos daños al organismo. Las desventajas percibidas no sólo son erróneas, sino bastante más generalizadas que las desventajas reales. Como veremos a continuación esto ocurre también con otros de los métodos modernos.

Respecto a los dispositivos intrauterinos (espiral y $\mathrm{T}$ de cobre), las principales ventajas señaladas por las participantes en los talleres, fueron las relacionadas con su uso prolongado y que no tienen que acordarse todos los días de su uso, en otras palabras, que su efectividad es independiente del coito. En cuanto a las desventajas, para la espiral todos los grupos de edad señalaron incorrectamente que produce cáncer y correctamente que en ocasiones produce sangrado; además, se mencionaron efectos supuestos tales como el "bebé nace con el espiral en la cabeza", o "se incrusta al embarazo" o "al hacerlo tosco, puede caerse o salirse". Aparentemente la mala fama de la pildora en cuanto al riesgo de cáncer, ha sido trasladada a los DIU. Con respecto a este método un punto que salió a relucir en las historias de vida es la vergüenza que sienten las mujeres de que el médico las examine. 
En el Hospital de Chepén ponían la espiral, no lo hice de supervergüenza, cada tres meses tener que ver al doctor, para que se encarne peor todavía (Juana, 32 años; Pueblo Nuevo).

Los óvulos anticonceptivos son poco conocidos, y entre sus desventajas se señaló la necesidad de usarlos justo antes de la relación sexual, cortándole espontaneidad y las sensaciones desagradables después de su uso "dicen se hace como una masa o baba", "se pone grasoso y es feo". Pocas mencionaron su baja efectividad si no se usa en combinación con el preservativo.

En torno a los anticonceptivos inyectables, todas las participantes de los talleres coincidieron en señalar su duración de 3 meses como su principal ventaja (aparentemente en relación con los ciclos orales), y entre las desventajas se indicó correctamente el problema del sangrado (spotting) pero exagerándolo al calificarlo de "hemorragia". Asimismo, se mencionaron manchas en la cara, subida de peso y deformaciones como supuestos efectos desventajosos de los inyectables.

En relación con la ligadura tubaria, la principal ventaja percibida por todos los grupos de edad, de todas las localidades, es su efectividad. Entre sus desventajas, la mayor parte eran incorrectas, tales como esperar hasta cumplir 50 años para obtener una ligadura, y que da dolor de cabeza. Por el contrario, los tres grupos más jóvenes señalaron correctamente su irreversibilidad como la principal desventaja de este método. Como ha sido demostrado en un estudio anterior, éste es el método que menor rechazo y temor genera entre los sectores populares del país. Sin embargo, está proscrito por la ley como método de planificación familiar, pese a su uso creciente (INANDEP-IPSS, 1988).

Con respecto a los métodos tradicionales (ritmo, retiro y lavados), las ventajas percibidas en su mayoría se basan en que son "naturales" (el ritmo y el retiro) y que por lo tanto "no malogran el organismo". Sin embargo, en el caso del lavado hubo una opinión mayoritaria de que no tiene ventajas por ser muy poco seguro, y esta opinión, en menor medida, se expresó también del retiro o coito interrumpido. Las desventajas percibidas del ritmo se refieren a la imposibilidad de tener relaciones "todos los días" y en segundo lugar a su baja efectividad. En el caso del retiro, la principal desventaja señalada fue la insatisfacción sexual y su poca efectividad; "el hombre no se aguanta y no lo saca". Finalmente, las desventajas del lavado son su baja efectividad y la inconveniencia de su uso "feo es correr a lavarse con bombilla", según las informantes de los talleres grupales.

Del preservativo o condón, muy pocas entrevistadas señalaron ventajas; la mayoría negó conocerlo, pues este método se asocia con 
las relaciones fuera de la unión. Las desventajas señaladas para su uso fueron múltiples, tanto las plausibles referidas a la disminución del placer, como a las supuestas fallas en su calidad "vienen rotos o picados" o a su fragilidad, "se revienta o rompe o se sale". Aunque en poca medida también hay quienes le temen al preservativo:

...él quería usar preservativos, pero yo le dije que "que iba a estar usando esas porquerías", tenía miedo de que se me quede adentro (Carmen, 24 años; Pueblo Nuevo).

Las cremas o jaleas vaginales son prácticamente desconocidas por lo que no pudo obtenerse mayor información sobre estos anticonceptivos.

En resumen, cabe notar la profusión de temores y conceptos errados acerca de los supuestos peligros a la salud de los métodos anticonceptivos modernos, siendo sorprendentemente los conceptos relativos a los métodos tradicionales bastante más exactos. Todo ello revela una pésima información de las usuarias potenciales acerca de la anticoncepción en general y de los métodos modernos en particular y la necesidad de robustecer y ampliar el contenido informativo de los programas de servicios en planificación familiar, tanto públicos como privados.

\section{Patrones de uso}

Las mujeres entrevistadas para las historias de vida se refirieron a su experiencia en el empleo de métodos de planificación familiar al tiempo que expresaron sus opiniones en torno a los mismos. Como vimos, son muy pocas las mujeres que usaron algún método para controlar su fecundidad antes de la unión, a pesar de que algunas tenían alguna información sobre ello y, además, eran sexualmente activas. La información por sí misma no garantiza el empleo de métodos anticonceptivos en el contexto de una sexualidad precoz, siendo necesario tomar en cuenta factores culturales mucho más complejos.

Al interior de la vida conyugal encontramos un patrón sumamente peculiar. La gran mayoría de la mujeres sin diferencia de edad o localidad sostuvo que sólo cabe regular la fecundidad después de haber tenido hijos. Es decir, que no existe casi demanda por espaciamiento de los primeros nacimientos y de lo que se trata más bien es de terminar con la procreación una vez que se han tenido más hijos de los deseados.

La explicación de este patrón de demanda responde básicamente a factores de tipo cultural. En los primeros años de matrimo- 


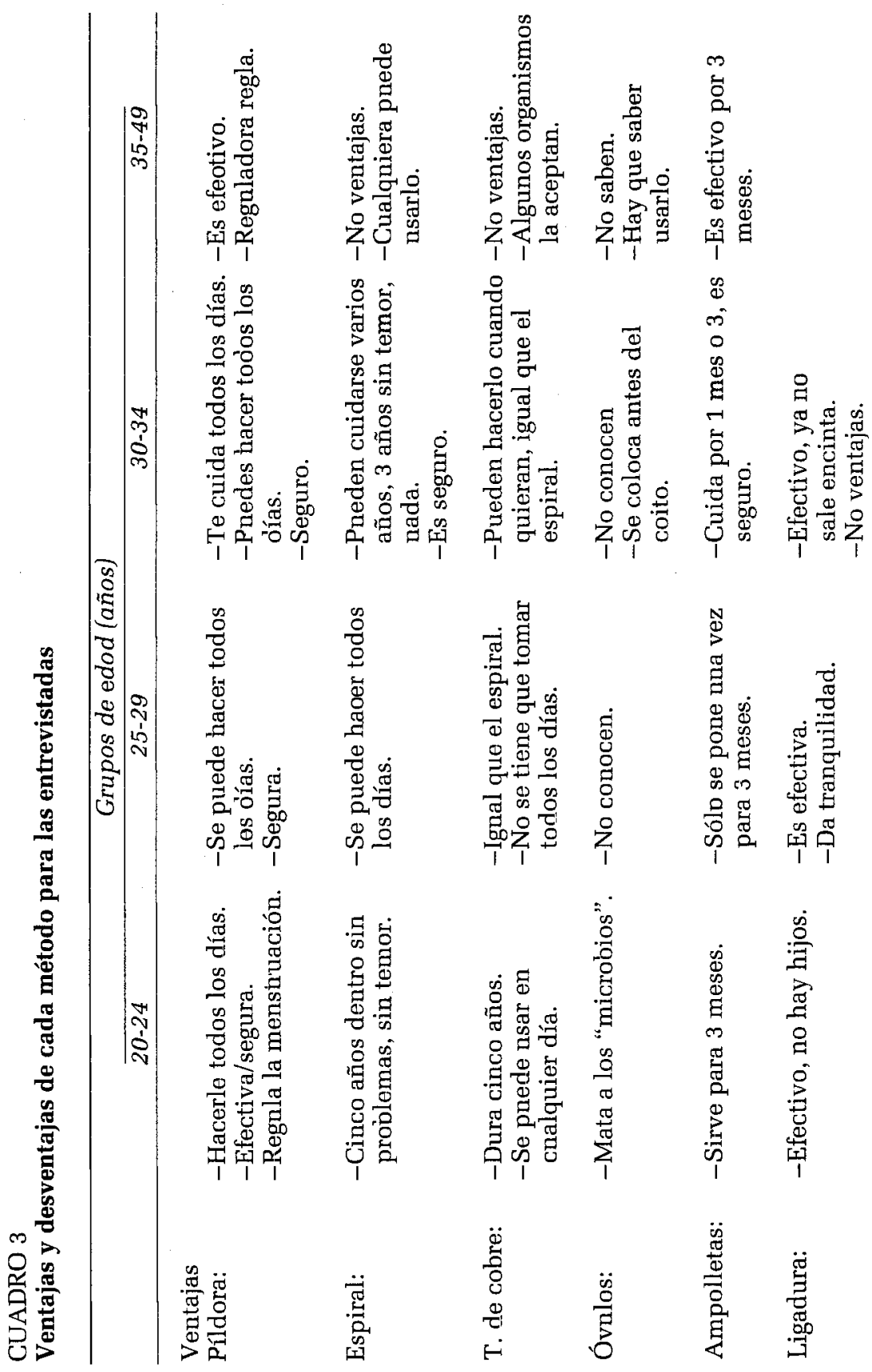


ESTUDIO COMPARATIVO DE MUJERES DE TRES CONTEXTOS DEL PERÚ 201
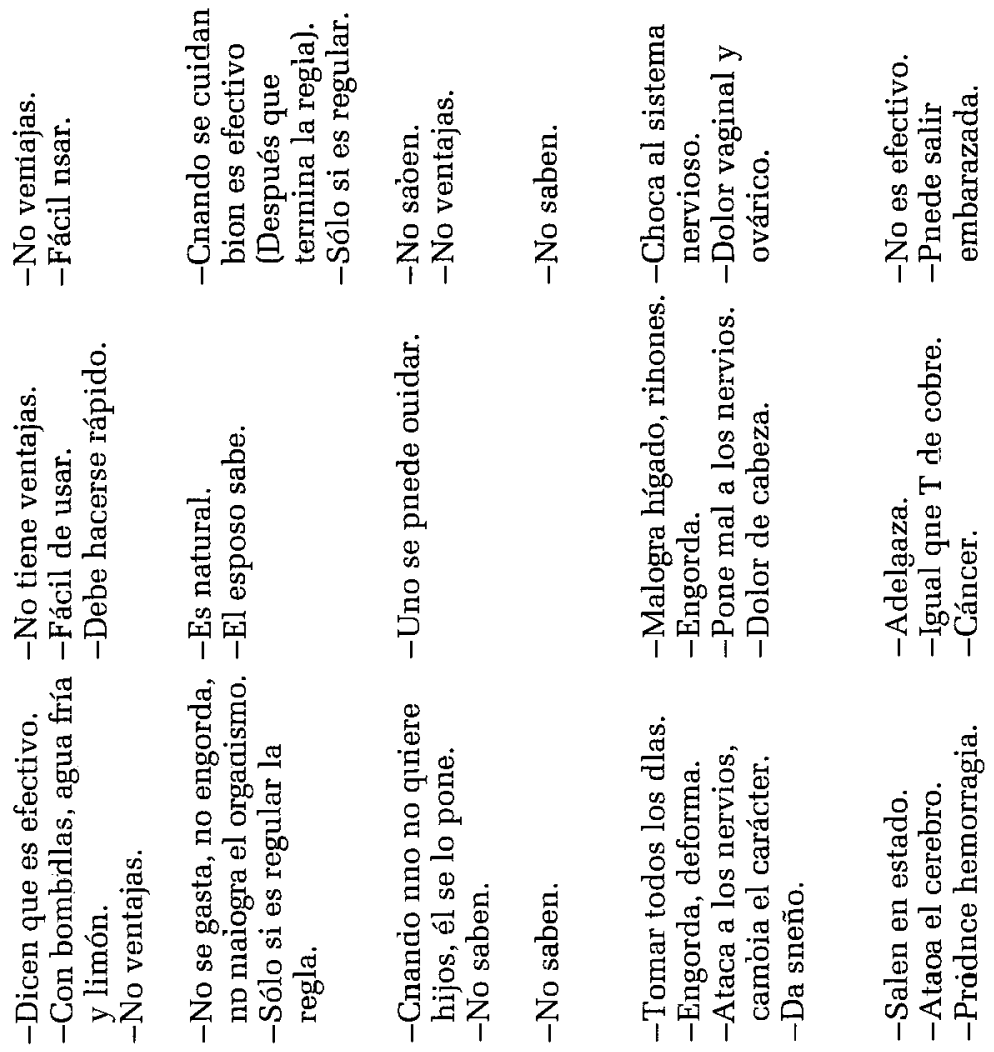

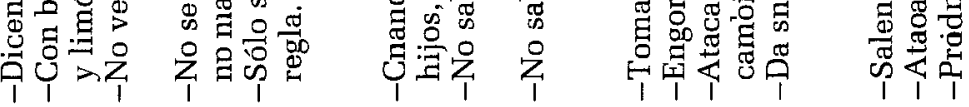

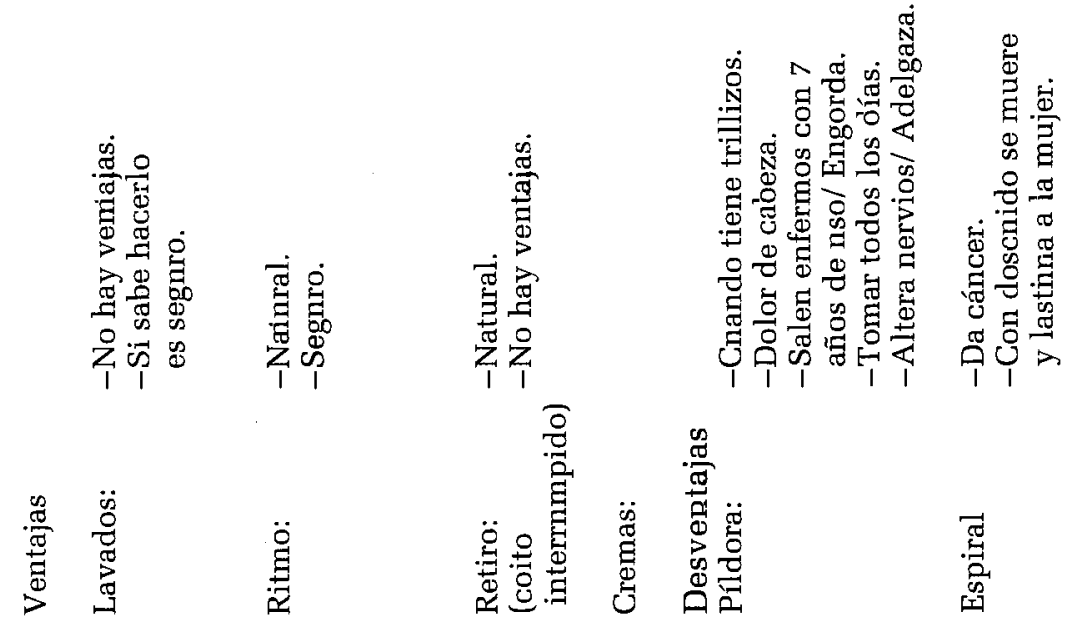




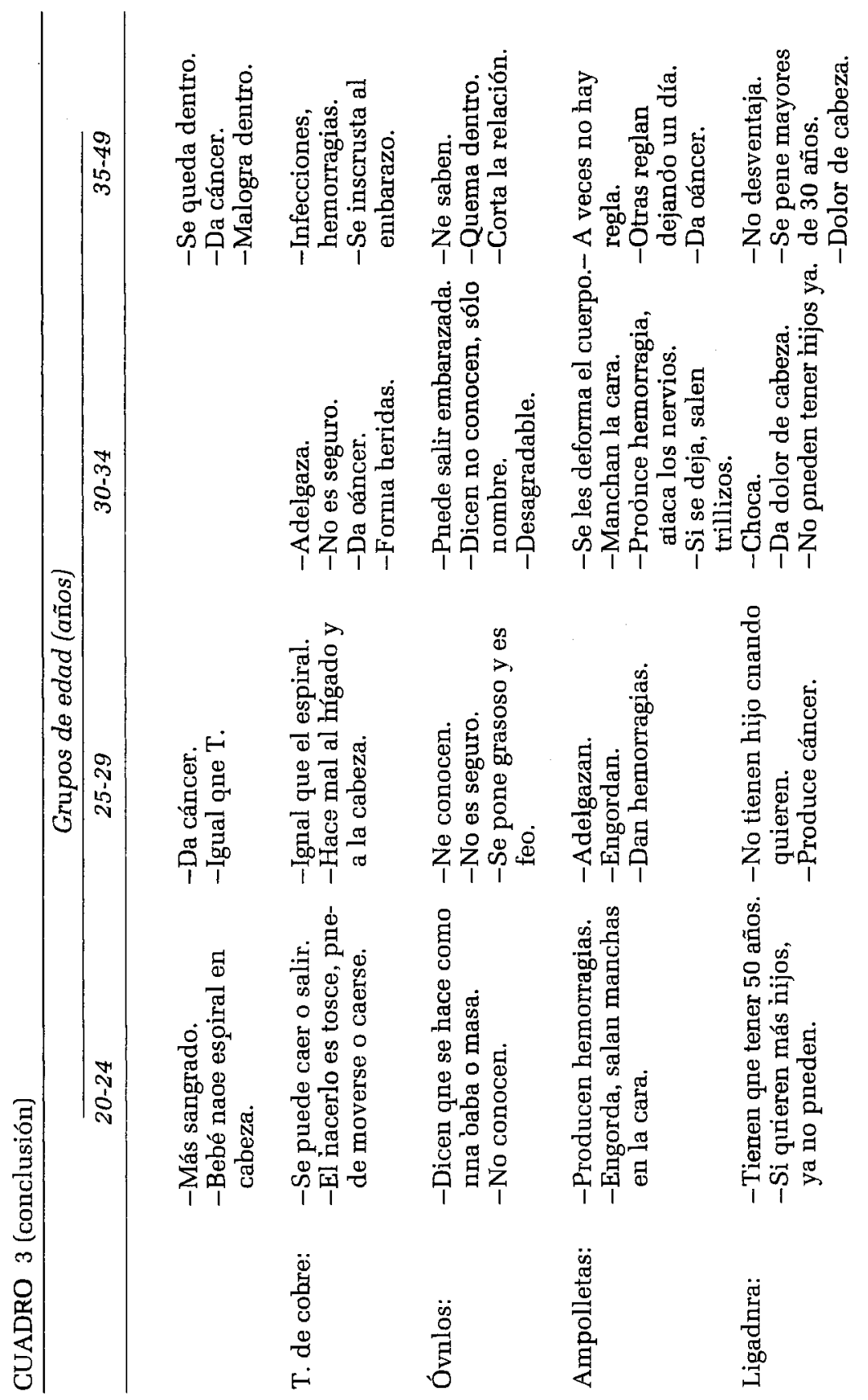


ESTUDIO COMPARATIVO DE MUJERES DE TRES CONTEXTOS DEL PERÚ 203
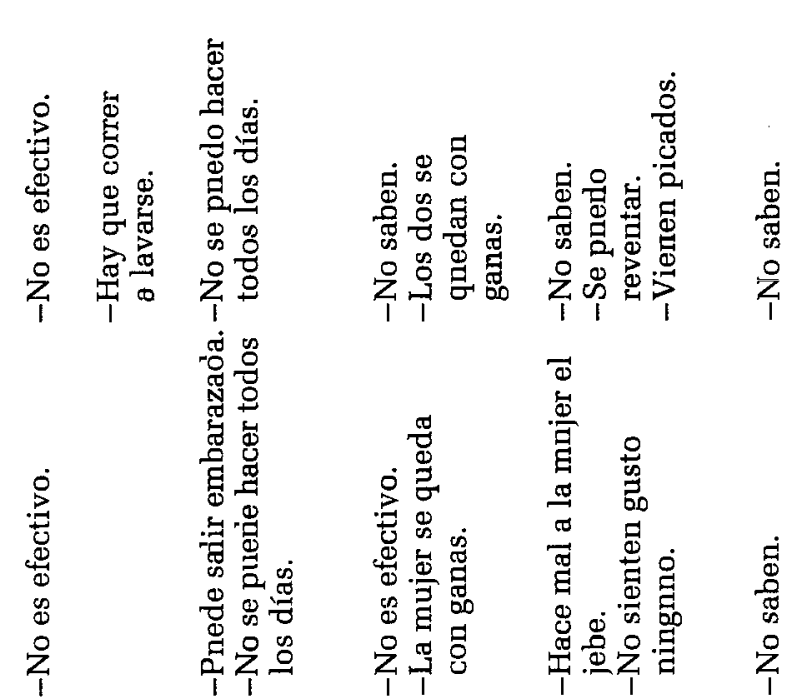

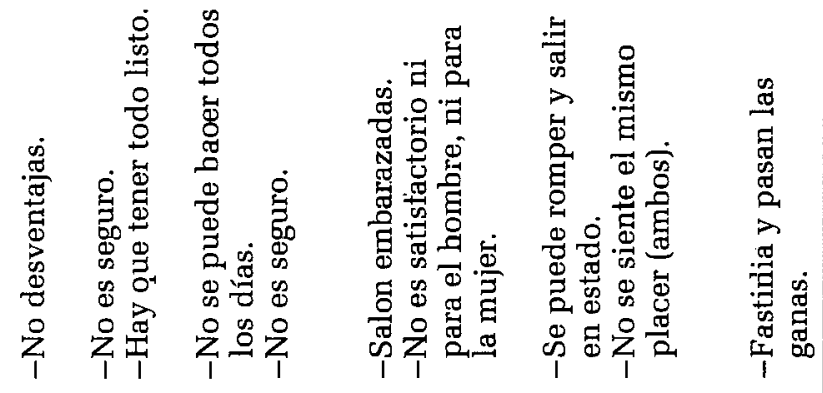

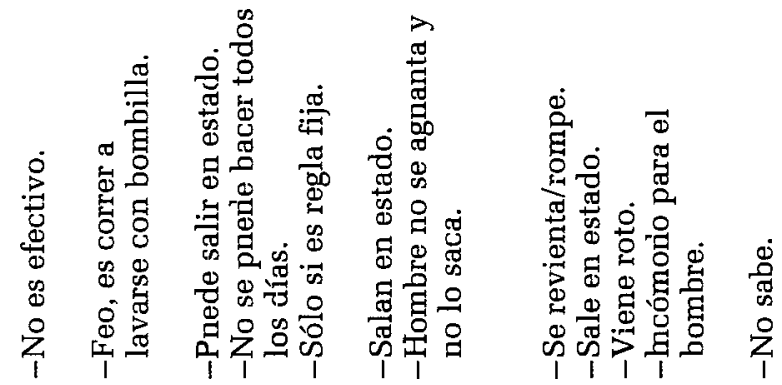

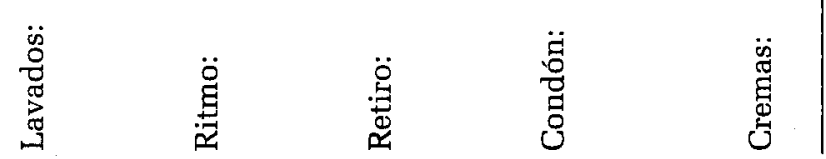


rúo, éste se consolida con la llegada de los hijos y el rol fundamental de la mujer es el de madre. Numerosos testimonios inciden en la presión familiar en el caso de aquellas mujeres que no salieron embarazadas inmediatamente después de la unión conyugal. La mujer casada debe sobre todo desear ser madre:

Después que me casé vi mi regla un mes y me puse ampolla que me duró cinco meses, recién después de seis meses salí embarazada. Yo quería cuidarme un tiempo, no le dije a mi esposo, él creía que yo era demorona, que no podía tener hijos, ya me quería llevar al doctor. Renegaba, yo calladita no le decía nada. Iba para los 27 , ya quería tener sus hijos. No teníamos prácticamente nada, no me quería casar y salir embarazada, uno tiene que ver primero su responsabilidad... (Elizabeth, 24 años; Pueblo Nuevo).

El tipo de métodos usados varía según el contexto cultural en el que la mujer se desarrolla. En la zona andina de Huaraz, según podemos apreciar en el cuadro 4 sólo cuatro mujeres de las 20 entrevistadas empleaban algún método moderno en el momento de la entrevista, mientras que en Pueblo Nuevo lo hacían 11 y en Lima 12. Entre los métodos modernos, en Pueblo Nuevo el preferido era la ligadura, seguido de cerca por la pildora. Es interesante señalar que ninguna de las entrevistadas tenía un DIU al momento de la entrevista, en Lima, por el contrario, el DiU era el método moderno más usado entre las entrevistadas. Es posible que el dinamismo y la disponibilidad de los servicios sea un elemento muy importante en la toma de decisiones de las mujeres.

Es indudable que los métodos de abstinencia periódica, tales como el ritmo y el retiro, son los preferidos, 26 mujeres los empleaban, siendo la zona tradicional de Huaraz donde esto se da en mayor medida (11 de 20). La preferencia de estos métodos está relacionada principalmente con prejuicios y temor con respecto a los métodos modernos.

Los temores y mitos se repiten una y otra vez en los distintos contextos afectando la posibilidad de las mujeres de decidir de una forma más equilibrada y veraz sobre su vida reproductiva. Esos prejuicios las llevan en algunos casos a despreciar a aquellas que usan los métodos modernos, aunque no lo digan directamente, tal y como podemos ver en el testimonio siguiente:

... mi esposo me cuida a mi natural, nada de regla, ni preservativo, nada de nada, no soy de ser así de tomar esas cosas; de esas que se introducen la espiral, después se ponen inyecciones; uno puede quedarse nerviosa, enferma de algo, de la cabeza, también del interior. De la espiral cada mes tienen que estar viéndose con doctor, sacándose, no me gusta (Elsa, 43 años; Lima). 
Los temores unidos a la falta de información desarrollan una actitud irracional que les impide proyectarse hacia el futuro pues todavía no han sobrepasado el número de hijos deseado. Es por esta razón que muchas de las jóvenes rechazan de plano el empleo de métodos modernos:

He escuchado de pastillas pero nunca voy a tomar eso, no me gusta. Nunca he tomado pastillas, sólo cuando estoy mal, me da miedo. De antes no sabía nada de cuidarme (Se cuida dando el pecho) (Marlene, 19 años; Lima).

Algunas de las entrevistadas son bastante efusivas al explicar las características negativas de los métodos:

Los métodos son malos dan inflamaciones, infecciones, altera el sistema nervioso porque es como un embarazo ficticio. También da cáncer y engorda. ¡Imagínate, cómo me voy a poner de ancho! Con la espiral ha muerto la hermana de una amiga, se le ha incrustado, así dice su misma hermana, da miedo (Merly, 33 años; Pueblo Nuevo).

Unas me decían, toma pastillas, otras me decían que no; te toca los nervios, te da cáncer, que chocaba al corazón pero yo de ver tantos hijitos tiernitos me puse en conversación con mi esposo, yo lloraba no tenía quien me ayude. Tomé Lindiol por una amiga que tomaba, yo tomé por mi cuenta. Después he cambiado a Ovral-21. Lindiol fuerte, me han dicho que todas las pastillas tienen el mismo poder para matar ese microbio (espermatozoides) y después de ahí me enfermé de los nervios. Me temblaba el cuerpo, gritaba, le pegaba a los niños, mucho me alteré, quería botar las cosas (Natalia, 24 años; Huaraz).

Frente a este panorama aterrador del que estaría plagado el futuro de las usuarias de métodos anticonceptivos, parece inexplicable la apertura de actitud que las mismas entrevistadas tienen ante la perspectiva de la ligadura. Esta actitud es bastante generalizada en los tres contextos estudiados:

... un hijo más y me ligo, para estar todo el tiempo con pastillas y cuidándome mejor que me corten todo lo que haya que cortar (Merly, 33 años; Pueblo Nuevo).

El uso de métodos modernos está vinculado en la mente de muchas mujeres con la falta de honestidad y rectitud que ellas mismas o sus maridos les atribuyen:

... mis amigas que usan tienen problemas con sus esposos, ya no se quieren, mucho se pelean (Maritza, 26 años; Pueblo Nuevo).

... fui al doctor, me hizo tomar unas pastillas mensuales, lo tomaba pero pienso que tal vez eso ha propiciado que me separe la primera vez... (Mercedes, 28 años; Lima). 
El rol del esposo o conviviente es crucial para la adopción del tipo de método, sea éste tradicional, como vimos, en el caso del ritmo, pero también en el caso de los métodos modernos.

Después que nació mi hija "mi esposo me hizo poner espiral" (Benita, 32 años; Lima).

Tuve mi varón y ahí "mi esposo me cuidaba dejando el líquido afuera" (retiro), un descuido de esos se le escapó el líquido como se dice vulgarmente y salí en estado de mi cuarto bebé (Frida, 35 años; Lima).

La opinión del cónyuge también resulta crucial para muchas mujeres, sobre todo las de menor nivel educativo, en relación con el uso de anticonceptivos:

A él no le gusta, que para qué cuidarme si así vienen de a dos, no sé cuales hay de métodos. No quiero llenarme de hijos y dar a luz que se sufre. Le voy a decir al doctor para que le haga entender (al esposo) (Elsa, 26 años; Pueblo Nuevo).

Mi esposo no quería (que use) pastillas. Decía que hacía mal para el hígado (Eva, 27 años; Pueblo Nuevo).

Hay veces tengo problemas con mi esposo porque yo quiero cuidarme. El doctor dice que no puedo tomar pastillas ni tener relaciones, eso hace problemas. Mi esposo no cree dice voy al doctor por manosear,... eso te gusta que te estén agarrando... me dice. Mi regla no es normal, se me adelanta una semana. Cuando es fija si se puede, cuando estoy cuidando con regla no tengo problemas con mi esposo, el está de acuerdo (María, 32 años; Huaraz).

Como se aprecia en la primera de las citas anteriores, la autoridad del médico tiene gran peso en las decisiones que toman las mujeres sobre su propia vida reproductiva, llegando incluso a interceder ante la oposición del marido. Frecuentemente las decisiones de la mujer no sólo con respecto al tipo de método usado sino incluso a si usar o no un anticonceptivo dependen de la opinión del médico:

Tengo espiral. Después del tercer hijo me recetó el mismo doctor. Me dijo si yo iba a completar la media docena de hijos o ahí no más. Yo le dije ahí no más. Yo fui después para que me lo saquen porque me habían dicho que daba cáncer pero el doctor me dijo que eso era importado, que no pasa nada (Lourdes, 43 años; Lima).

En el trabajo de mi esposo me decían, ponte T de cobre, a ellos no les conviene que tengamos más hijos porque cada uno de ellos es asegurado y ganamos asignación mensual. Me obligaron casi a ponerme, me revisó (el doctor) me dijo que mi útero estaba perfecto. Recién hace dos o tres meses me ha puesto, creo que es T de cobre (Juana, 32 años; Lima). 
Él, mi esposo es el que más me dice que vaya, que me cuide desde un principio. Ayer le estaba diciendo, ya pues hay que ir. Él ahora hace afuera (retiro), me da miedo, a una tía le han puesto el espiral y le ha dado como hemorragia, hasta estuvo internada en el hospital, también nos explicaron de la $\mathrm{T}$ de cobre. Yo quería ligadura pero eso te hacen después de tres o cuatro hijos. El doctor me dijo, tú eres tierna, tienes dos hijos, a la doctora le pedí en mi segundo parto me aceptó todo, pero después me dijo... no, todavía eres muy joven, mi esposo también quería (Dorlisa, 29 años; Huaraz).

En conclusión, la mujer de sectores populares anhela una mayor capacidad de decisión sobre su vida reproductiva, pero los temores, rumores y actitudes de esposos y médicos frecuentemente interfieren con sus propias decisiones en uno u otro sentido. Es este complejo cultural, las nociones erradas y el autoritarismo, más que la accesibilidad económica o física a los anticonceptivos, son los que impiden a la mujer actuar libremente con respecto a lo más importante para definir su rol y su futuro, su conducta sexual y reproductiva. Por estar profundamente arraigada en la cultura local, estas barreras son más difíciles de vencer, sobre todo las referidas a los supuestos daños a la salud de los anticonceptivos. La salud para la mujer de bajos ingresos es vital no sólo por el alto costo que implica su recuperación, sino también por ser ellas las únicas o principales responsables del trabajo físico en el hogar y aún fuera de él.

CUADRO 4

Uso actual de anticonceptivos (mujeres unidas)

\begin{tabular}{lcccc}
\hline & Huaraz & Pueblo Nuevo & Lima & Total \\
\hline - No usa & $5^{*}$ & $3^{* *}$ & $3^{* * *}$ & 11 \\
- Usa & 15 & 17 & 17 & 49 \\
- Ritmo & 10 & 6 & 3 & 19 \\
- Retiro & 1 & 1 & 2 & 4 \\
- Preservativo & - & - & 1 & 1 \\
- Óvulos & - & 3 & - & 1 \\
- Orales & 2 & - & 2 & 7 \\
- DIU & 2 & 4 & 5 & 7 \\
- Ligadura & - & 2 & 3 & 7 \\
- Inyectables & - & 20 & 1 & 3 \\
Total & 20 & 20 & 60 \\
\hline
\end{tabular}

* Las cinco no usuarias de Huaraz manifestaron tener al esposo ausente (dos), estar separadas (dos) o ser viuda (una).

** De las tres mujeres que declararon no usar un método; una estaba embarazada y otra separada.

***De las tres no usuarias, una está lactando. 


\section{El aborto}

En Perú, al igual que en el resto de América Latina, el aborto es un fenómeno difícil de medir, no sólo porque al ser condenado por la ley no se le menciona fácilmente, sino porque es socialmente censurado razón por la que las mujeres ocultan la verdad a pesar de no correr un peligro inminente. Por este motivo no podemos asegurar que en nuestro estudio, las que declararon haberse practicado un aborto sean las únicas que lo hicieron.

De las 60 mujeres entrevistadas sólo dos declararon haberse hecho un aborto inducido, es interesante destacar que ambas se encontraban separadas de su pareja en el momento del aborto. Este número parece muy reducido; sin embargo, si pasamos al plano de las intenciones, encontramos que en total 17 mujeres intentaron abortar con o sin éxito, o intentarían hacerlo de encontrarse nuevamente embarazadas. En Huaraz, ciudad de la sierra peruana, es donde encontramos un mayor número de mujeres que estarían dispuestas a recurrir a un aborto. Es importante destacar que es también en esa zona donde se presenta una menor incidencia del uso de métodos anticonceptivos modernos, estando las mujeres en riesgo de tener un embarazo no deseado.

La decisión de abortar es difícil e implica no solamente problemas morales y emocionales, sino también problemas de orden práctico en los que no sólo se ve involucrada la pareja sino también el personal de salud y hasta los amigos. Es por esta razón que algunas veces las mujeres continúan con un embarazo no deseado a pesar de haber decidido terminarlo.

Si he querido hacer, primero quise al segundo poniéndome ampolleta pero no me pasó nada, y con la tercera fuimos donde el médico, le pagamos inclusive, me puso en la camilla, no me puso anestesia, nada, después me dio pastillas para la hemorragia todo, eso fue en Huaraz. Yo me fui a mi casa... un mes después le digo a mi esposo mi barriga está grande, de repente algo me ha dejado dentro, una tripa. Después mi esposo fue a buscar al doctor y le confesó que no había hecho, que no se iba a arriesgar, que sólo limpieza le he hecho. No lo podía denunciar pues mi esposo también iba a la cárcel, devolvió el dinero (Natalia, 24 años; Huaraz).

Como podemos ver en este testimonio la mujer no es libre para tomar su propia decisión, sufriendo las consecuencias de la voluntad de otros, en este caso la del médico. 


\section{Comentario final}

Como se puede apreciar con base en la información hasta aquí presentada, los cambios demográficos y en especial el descenso de la fecundidad, están aún por ocurrir en los sectores populares de los medios rurales y andinos tradicionales. En aquellos casos en que la contracepción moderna es utilizada, ello no ha implicado un cambio cualitativo en la cultura sexual; la desinformación, temor, represión, dominación y autoritarismo del varón caracterizan la vida sexual y reproductiva de estas mujeres. Lo que las encuestas miden como dimensiones de modernidad y cambio, es decir el aumento de la anticoncepción eficaz y el descenso de la fecundidad, no implican necesariamente un cambio cualitativo en las relaciones de pareja y en la calidad de vida para las mujeres de sectores populares. Para ello se requiere un proceso mucho más profundo y lento que implique una modificación en las relaciones de poder y en la cultura de género, no sólo en el nivel de la sociedad sino también a nivel doméstico y familiar. Es decir un cambio cualitativo y no únicamente cuantitativo. Viene al caso la frase del poeta Valleijo, "Desgraciadamente hombres humanos, hay hermanos muchísimo que hacer...”.

\section{Bibliografía}

Aramburú, Carlos y Dina Li (1989), "Estudio integrado de la fecundidad", Lima, INANDEP (mimeo.).

Bongaarts, John, O. Frank y R. Lesthaeghe (1989), "The proximate determinants of fertility", en Acsadi, Johnsons-Acsadi y Bulatao (ed.), Population Growth and Reproduction in Sub-Saharian Africa: Technical Analysis of Fertiliy and its Consequences, Washington, The World Bank.

Caldwell, John, P.H. Reddy y P. Cadwell (1988), The Causes on Demographic Change: Experimental Research in South India, Madison, Wisconsin, University of Wisconsin Press.

Chakiel, Juan y Susana Schkolinik (1990),“América Latina: transición de la fecundidad en el periodo 1950-1990", en Seminario de Transición de la Fecundidad en América Latina, Buenos Aires, IUSSP, 3-6 de abril.

Coale, A. y S. Watkins (1986), The decline of fertility in Europe, Princeton, New Jersey, Princeton University Press.

Easterlin, Richard (1978), "The Economics and Sociology of Fertility: a Synthesis", en Charles Filly (ed.), Historical Studies of Changing Fertility, Princeton, New Jersey, Princeton University Press.

Encuesta Demográfica y de Salud Familiar (EDDES) (1991-1992), Instituto Nacional de Estadística e Informática, 1992.

Ferrando, Delicia y Carlos Aramburú (1990), "La transición de la fecun- 
didad en el Perú", en Seminario de Transición de la Fecundidad en América Latina, Buenos Aires, IUSSP, 3-6 de abril.

INANDEP-IPSS (1988), La anticoncepción en el Perú: mito y realidad, Lima, Perú.

MacLaren, Angus (1990); A History of Contraception, from Antiquity to the Present day, Basil Blackwell, Cambridge, Mass/Oxford.

Notestein, Frank (1945), "Population-The Long view", in T. Schutlz (ed.), Food for the World, University of Chicago Press, pp. 33-62.

Samuel, Olivia, Susana Lerner y André Quesnel (1993), "Hacia un informe demoantropológico de la nupcialidad y su relación con nuevos esquemas de procreación", trabajo presentado al xII Congreso Internacional de Ciencias Antropológicas y Etnológicas, México, 29 de junio-5 agosto. 